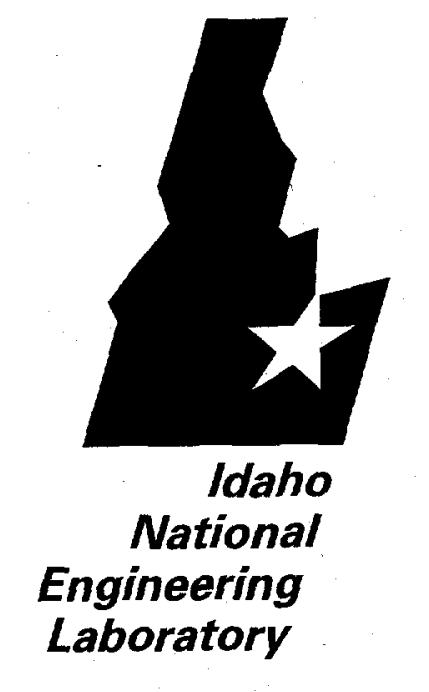

June 1998

\title{
Low-Level Radioactive Waste Form Qualification Testing
}

\section{RECEIVED \\ SEP 14 १९98 \\ OSTI}

Manohar S. Sohal

Doug W. Akers

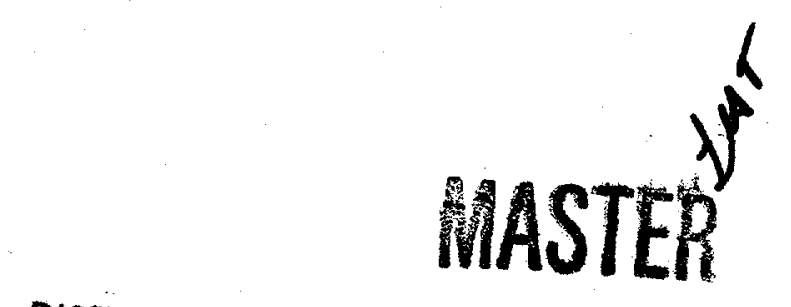

DATRUEUTION OF THS COCUMENT IS UNLMITED

LOCKHEED MA ATIN 


\section{DISCLAIMER}

This report was prepared as an account of work sponsored by an agency of the United States Government. Neither the United States Government nor any agency thereof, nor any of their employees, makes any warranty, express or implied, or assumes any legal liability or responsibility for the accuracy, completeness, or usefulness of any information, apparatus, product, or process disclosed, or represents that its use would not infringe privately owned rights. Reference herein to any specific commercial product, process, or service by trade name, trademark, manufacturer, or otherwise does not necessarily constitute or imply its endorsement, recommendation, or favoring by the United States Government or any agency thereof. The views and opinions of authors expressed herein do not necessarily state or reflect those of the United States Government or any agency thereof. 


\section{DISCLAIMER}

Portions of this document may be illegible electronic image products. Images are produced from the best available original document. 


\title{
Low-Level Radioactive Waste Form Qualification Testing
}

\author{
Monohar S. Sohal \\ Doug W. Akers
}

Published June 1998

Idaho National Engineering and Environmental Laboratory

National Low-Level Waste Management Program

Lockheed Martin Idaho Technologies Company

Idaho Falls, Idaho 83415

\author{
Prepared for the \\ U.S. Department of Energy \\ Assistant Secretary for Environmental Management \\ Under DOE Idaho Operations Office \\ Contract DE-AC07-941D13223
}




\section{EXECUTIVE SUMMARY}

This report summarizes activities that have already been completed as well as yet to be performed by the Idaho National Engineering and

Environmental Laboratory (INEEL) to develop a plan to quantify the behavior of radioactive low-level waste forms. It briefly describes the status of various tasks, including DOE approval of the proposed work, several regulatory and environmental related documents, tests to qualify the waste form, preliminary schedule, and approximate cost. It is anticipated that INEEL and Brookhaven National Laboratory will perform the majority of the tests. For some tests, services of other testing organizations may be used. It should take approximately nine months to provide the final report on the results of tests on a waste form prepared for qualification. It is anticipated that the overall cost of the waste quantifying service is approximately $\$ 150,000$. 


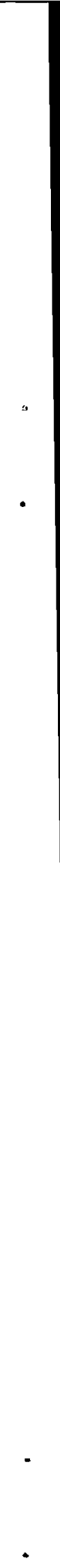




\section{CONTENTS}

EXECUTIVE SUMMARY

iii

ACKNOWLEDGMENTS

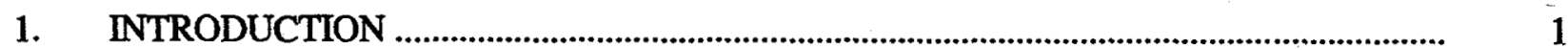

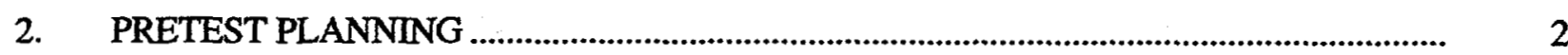

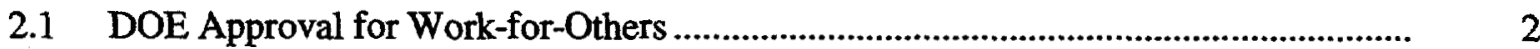

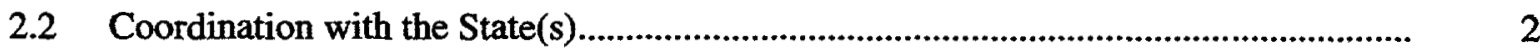

2.3 Statement of Work for Performing the Tests ............................................................

2.4 Negotiated Cost Estimate and INEEL Approval ...................................................... 2

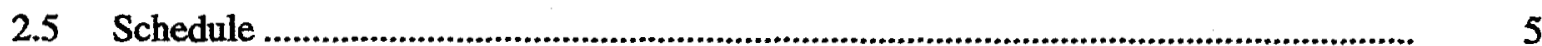

2.6 Conflict of Interest Determination ....................................................................

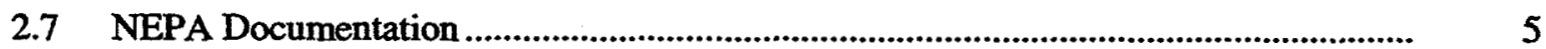

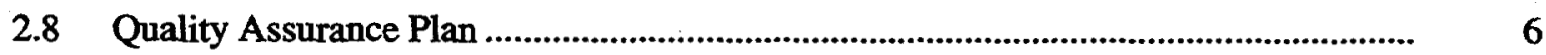

2.9 Independent Hazard Review ........................................................................... 7

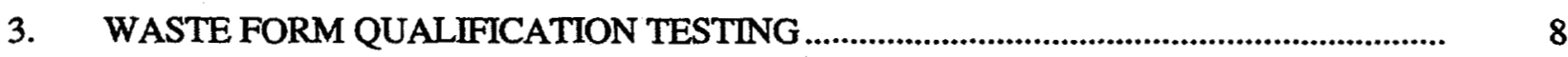

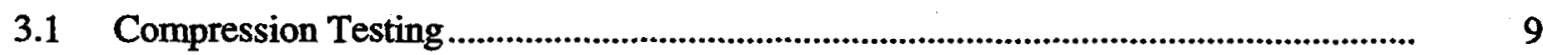

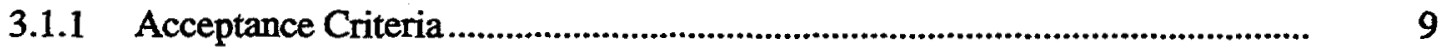

3.1.2 Testing Methodology ................................................................................ 9

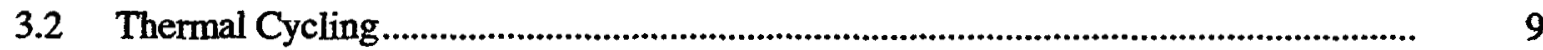

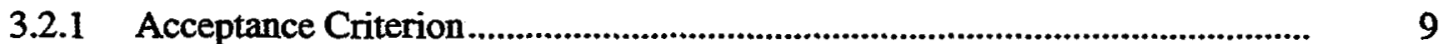

3.2.2 Testing Methodology ............................................................................... 10

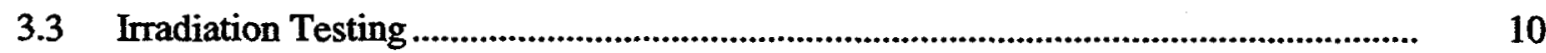

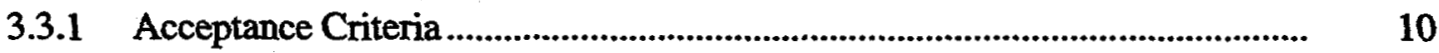

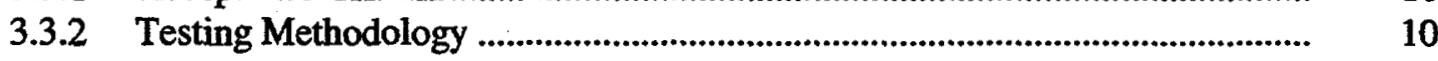

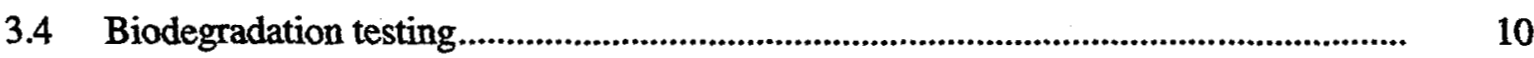

3.4.1 Acceptance Criteria .............................................................................. 10

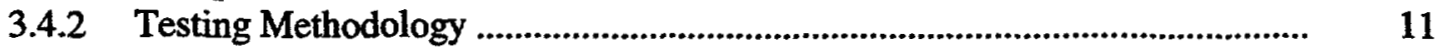




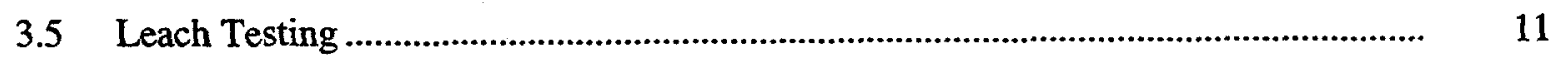

3.5.1 Acceptance Criteria .................................................................................... 11

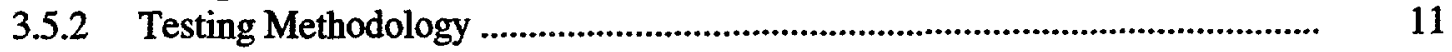

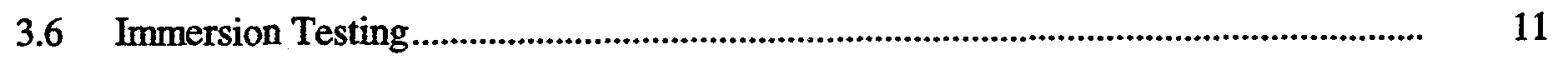

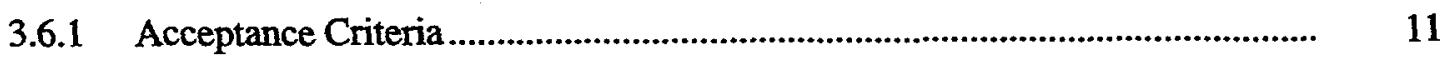

3.6.2 Testing Methodology .............................................................................. 11

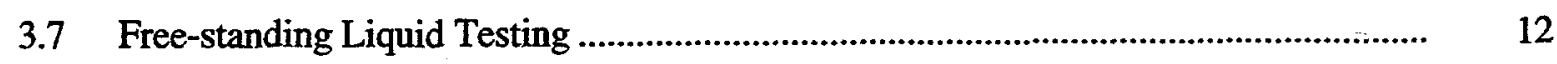

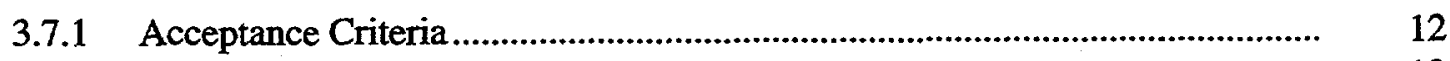

3.7.2 Testing Methodology ............................................................................. 12

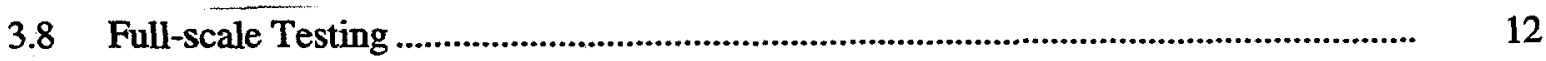

4. WORK SCHEDULES, QUALITY ASSURANCE, AND COSTS .................................... 13

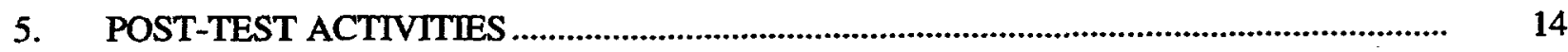

6. CONCLUSIONS................................................................. 15

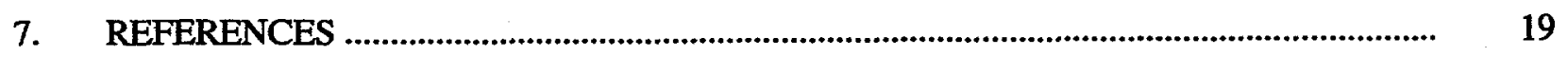

Appendix A-DOE Approval

Appendix B-Work for Others Cost Form

Appendix C-Conflict-of-Interest Determination

Appendix D-NEPA Documentation

Appendix E-Quality Assurance Plan

Appendix F-Draft Test Planx

\section{TABLES}

1a. Schedule and labor estimates for Waste Form Qualification Tests (INEEL).......................... 3

1b. Schedule and labor estimates for Waste Form Qualification Tests (BNL) .......................... 4

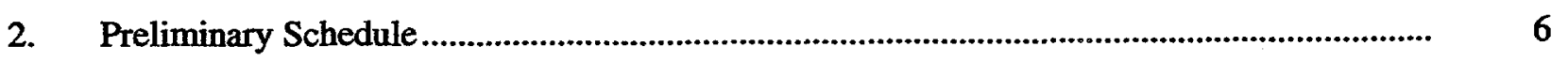

3. Protocol for Low-Level Waste Form Qualification Testing............................................... 17 


\section{Low-Level Radioactive Waste Form Qualification Testing}

\section{INTRODUCTION}

The Nuclear Regulatory Commission's (NRC's) “Technical Position on Waste Form, Revision 1, January $1991^{1}$," requires that buried waste forms preserve their structural integrity and be capable of resisting degradation that could cause excessive release of radioactive constituents to the environment. The NRC has specified a series of tests in the Technical Position to quantify the behavior of waste forms under simulated burial conditions. Waste generators or waste treatment process vendors who provide these test data, and show that their waste formulations meet regulatory requirements, may receive approval for their waste formulations to be disposed of at licensed waste facilities by the appropriate regulatory agency.

The Idaho National Engineering and Environmental Laboratory (INEEL) and Brookhaven National Laboratory (BNL) have longstanding expertise in the development and testing of a wide range of waste forms under programs sponsored by both the NRC and the Department of Energy (DOE). These capabilities are available to qualify new waste formulations that may be used for disposal at a repository site. A brief description of the tests that INEEL and BNL can perform for industry to meet the guidance of the NRC Branch Technical Position is presented in Section 3. This document summarizes the steps that have been taken or will be taken to perform the NRC Branch Technical Position Tests, description of the tests, and the labor/cost estimates to complete these tests. A protocol for the benefit of the users of the testing services is also included in this report. A parallel test program for the high integrity containers (HICs) and macro-encapsulated waste forms will be prepared and issued as a separate report. These services will provide some functions of the now defunct NRC process of reviewing low-level waste topical reports.

This work scope is primarily focused on the qualification testing of new waste forms for the National Low-Level Waste Management Program. Therefore, environmental issues and testing costs are limited as tests are primarily performed on nonradioactive samples. 


\section{PRETEST PLANNING}

Several steps need to be taken prior to performing the tests to ensure that INEEL and BNL meet the requirements established by DOE to perform the proposed work and also delivers the test results in a cost effective and timely manner to the waste generators. The following steps either have already been taken or are under progress so that all the necessary planning requirements are completed prior to the start of any testing.

\subsection{DOE Approval for Work-for-Others}

The INEEL and BNL are DOE laboratories. Therefore, to perform any work for a customer other than the federal government or federal agencies, INEEL and BNL have to obtain permission from DOE. In August 1996, a work-for-others (WFO) package (\#96832) was approved by DOE-Idaho. DOE has agreed in principle to perform this work and has approved an umbrella agreement to proceed with the work. A copy of the approval is given in Appendix A. However, this work can also be classified under a category termed "cosponsored" work. In this category, cost of performing the work is borne by both federal and non-federal agencies. A benefit of this classification is that the DOE may waive part or all of the DOE added factor and depreciation cost, amounting to approximately $15 \%$ of the total cost. The DOE-Idaho has approved a request for classifying a hypothetical, but very likely work in the "cosponsored" category.

\subsection{Coordination with the State(s)}

Before starting the tests for the waste processing company. the INEEL will coordinate the tests to be performed with the Host State Technical Coordinating Committee and Conference of Radiation Control Program Directors before and after performing the tests. In addition, the regulatory agency(ies) of one or more states, who may be the eventual recipient of the processed waste, may also be contacted. The purpose of the coordination is to optimize the number of tests to be performed to characterize the processed waste.

\subsection{Statement of Work for Performing the Tests}

The INEEL project manager and/or a representative will visit the waste processing company to discuss the tests to be performed and develop a mutually agreed Statement of Work (SOW). Basically, the tests will be the same or similar to those described in Section 3 of this report. Any deviation from these tests or additional tests will be clearly defined in the SOW. The agreed SOW will form the basis for developing the cost estimate and schedule.

\subsection{Negotiated Cost Estimate and INEEL Approval}

A cost estimate will be developed to complete the work based on the SOW developed in Section 2.2. A preliminary generic labor estimate is presented in Table 1a for INEEL and Table $1 \mathrm{~b}$ for BNL to perform all the tests. The cost estimate will be approximately equal to that corresponding to these labor estimates plus some surcharge by the DOE to perform this service for a non-federal agency and charges to review the test report by the state where the processed wasted may be sent for deposition. The preliminary estimate is approximately 150,000 . This estimate will be agreed upon between the waste generator and the INEEL. A blank form used by INEEL to develop a cost estimate for any WFO is presented in Appendix B. 
Table 1a. Schedule and labor estimates for Waste Form Qualification Tests (INEEL).

\begin{tabular}{|c|c|c|c|}
\hline Task & Duration & $\begin{array}{l}\text { Labor } \\
\text { (h) }\end{array}$ & Comments \\
\hline $\begin{array}{l}\text { 1.0 Customer Assessment/ } \\
\text { Requirements }\end{array}$ & & & $\begin{array}{l}\text { Ensure customer, } \mathrm{NRC} \text {, and waste } \\
\text { site requirements are well defined }\end{array}$ \\
\hline $\begin{array}{l}1.1 \text { Review customer } \\
\text { requirements }\end{array}$ & $\begin{array}{l}2 \text { weeks } \\
\text { Travel-\$4.0K }\end{array}$ & $60 \mathrm{~h}$ & $\begin{array}{l}\text { Review customer and waste site } \\
\text { requirements }\end{array}$ \\
\hline $\begin{array}{l}2.0 \text { Test Plan and } \\
\text { Environmental Review }\end{array}$ & & & $\begin{array}{l}\text { Includes customer req., ES\&H, and } \\
\text { quality review }\end{array}$ \\
\hline 2.1 SOW \& Test plan & 4 weeks & $160 \mathrm{~h}$ & Includes quality review \\
\hline 2.2 Coordinate with States & 1 week & $40 \mathrm{~h}$ & $\begin{array}{l}\text { Coordinate SOW \& Test Plan with } \\
\text { the concerned states }\end{array}$ \\
\hline $\begin{array}{l}\text { 2.3 QA Plan \& IHRG } \\
\text { review }\end{array}$ & 3 weeks & $100 \mathrm{~h}$ & $\begin{array}{l}\text { Revisit generic QA plan \& also } \\
\text { NEPA documentation }\end{array}$ \\
\hline 2.4 Waste disposal plan & 2 weeks & $40 h$ & $\begin{array}{l}\text { Waste disposal - } \\
\text { radioactive/nonradioactive samples }\end{array}$ \\
\hline 3.0 Waste Form Tests & & & $\begin{array}{l}\text { Work scope for Branch Technical } \\
\text { Position tests }\end{array}$ \\
\hline $\begin{array}{l}3.1 \text { Compression Testing } \\
\text { (NR) }\end{array}$ & $\begin{array}{l}\text { Individual compressive strength } \\
\text { tests-5 specimens }\end{array}$ & $20 \mathrm{~h}$ & $\begin{array}{l}\text { Labor includes preparation, } \\
\text { cleanup and QA }\end{array}$ \\
\hline 3.2 Thermal cycling (NR) & $\begin{array}{l}6 \mathrm{~d} \text { (for } 30 \text { cycles), followed by } \\
\text { compression testing of } \\
5 \text { specimens }\end{array}$ & $40 \mathrm{~h}$ & $\begin{array}{l}\text { Labor includes subsequent } \\
\text { compression testing of } 5 \\
\text { specimens, QA, photography, and } \\
\text { cleanup }\end{array}$ \\
\hline 3.3 Irradiation testing (NR) & $\begin{array}{l}\text { Up to } 200 \text { hrs in the ATR to } \\
\text { achieve a dose of } 10^{8} \text { rads for a } \\
\text { batch of any size followed by } \\
\text { compression testing. Note- } \\
\text { only a single irradiation is } \\
\text { needed for all specimens }\end{array}$ & $40 \mathrm{~h}$ & $\begin{array}{l}\text { Labor includes irradiation } \\
\text { dosimetry and subsequent } \\
\text { compression testing of } 4 \\
\text { specimens, photography, } \mathrm{QA} \text {, and } \\
\text { cleanup }\end{array}$ \\
\hline 3.4 Biodegradation (NR) & $\begin{array}{l}21 \text { d each for ASTM G21 and } \\
\text { G22 tests on batches of } 5 \\
\text { specimens, followed by } \\
\text { compression testing of } \\
\text { specimens }\end{array}$ & $\begin{array}{l}60 \mathrm{~h} \text { (batch } \\
\text { of 5) }\end{array}$ & $\begin{array}{l}\text { Labor includes subsequent } \\
\text { compression testing of } 5 \\
\text { specimens, photography, } \mathrm{QA} \text {, and } \\
\text { cleanup. }\end{array}$ \\
\hline $\begin{array}{l}\text { 3.5 Leach Testing- } \\
\text { Radioactive (R) }\end{array}$ & $\begin{array}{l}90 \mathrm{~d} \text { standard, but } 5 \mathrm{~d} \text { for } \\
\text { cementitious waste forms. }\end{array}$ & $\begin{array}{l}160 \mathrm{~h} \text { per } \\
\text { batch of } \\
3 \text { standard } \\
\text { specimens }\end{array}$ & $\begin{array}{l}\text { Labor includes sample spikes, } \\
\text { waste form preparation, sampling } \\
\text { of leachates, analysis using RML } \\
\text { germanium detector, and QA. }\end{array}$ \\
\hline 3.6 Immersion Testing & $90 \mathrm{~d}$ & $\begin{array}{l}40 \mathrm{~h} \text { (batch } \\
\text { of 5) }\end{array}$ & $\begin{array}{l}\text { Labor includes photography and } \\
\text { cleanup, as necessary. }\end{array}$ \\
\hline $\begin{array}{l}\text { 3.7 Free-standing Liquids } \\
\text { (NR) }\end{array}$ & $2 \mathrm{~h}$ & $2 \mathrm{~h}$ & $\begin{array}{l}\text { This test will be conducted by } \\
\text { generator if they are prepared full- } \\
\text { scale waste forms. }\end{array}$ \\
\hline 3.8 Full-scale Testing (NR) & $\begin{array}{l}90 \text { days to obtain samples, } \\
\text { perform compression, } \\
\text { immersion, and chemical } \\
\text { analysis to assess homogeneity }\end{array}$ & $\begin{array}{l}200 \mathrm{~h} \\
\$ 4.0 \mathrm{k} \text { travel }\end{array}$ & $\begin{array}{l}\text { Full-scale testing will be conducted } \\
\text { on samples provided by the } \\
\text { generator. INEEL will provide QA } \\
\text { and sampling requirements, and an } \\
\text { observer. (Preliminary estimate) }\end{array}$ \\
\hline
\end{tabular}


Table 1a. (continued).

\section{Task}

4.0 Waste Disposal

5.0 Final Report

Preparation

6.0 Facilitate Acceptance \& Review of the Report by the State(s)

7.0 Project Management
Labor

(h)

$60 \mathrm{~h}$

3 man-weeks

5 man-weeks

$240 \mathrm{~h}$

2 man-weeks

$60 \mathrm{~h}$

$160 \mathrm{~h}$

\section{Comments}

Because material will be precharacterized, nonradioactive, disposal costs will be minimal.

The report will include results and analyses of all laboratory-scale tests for a given waste stream, QA results, and a summary of the ability of the waste formulation to meet NRC requirements.

Coordinate the test report with the concerned States' representatives

Project management and coordination

Table 1b. Schedule and labor estimates for Waste Form Qualification Tests (BNL).

\begin{tabular}{|c|c|c|c|}
\hline Test & Test Duration & $\begin{array}{l}\text { Labor } \\
\text { (h) }\end{array}$ & Comments \\
\hline 3.1 Compression Testing & $2.0 \mathrm{~h} /$ specimen & $\begin{array}{l}10 \mathrm{~h} \text { (batch } \\
\text { of 5) }\end{array}$ & $\begin{array}{l}\text { Labor includes time for specimen } \\
\text { preparation, dimensioning, and } \\
\text { cleanup. }\end{array}$ \\
\hline 3.2 Thermal Cycling & $\begin{array}{l}6 \mathrm{~d} \text { (for } 30 \text { cycles), followed } \\
\text { by compression testing of } \\
5 \text { specimens at } 2 \mathrm{~h} / \text { specimen. }\end{array}$ & $20 \mathrm{~h}$ & $\begin{array}{l}\text { Labor includes subsequent } \\
\text { compression testing of } 5 \\
\text { specimens, photography, and } \\
\text { cleanup. }\end{array}$ \\
\hline 3.3 Irradiation Testing & $\begin{array}{l}250 \mathrm{~h} \text { to achieve a dose of } 10^{8} \\
\text { rad for a batch of } 2 \text { specimens, } \\
\text { followed by compression } \\
\text { testing at } 2 \mathrm{~h} / \text { specimen. Note } \\
\text { that two separate irradiations } \\
\text { are needed }-2 \text { specimens per } \\
\text { irradiation. }\end{array}$ & $20 \mathrm{~h}$ & $\begin{array}{l}\text { Labor includes irradiation } \\
\text { monitoring, subsequent } \\
\text { compression testing of } 4 \\
\text { specimens, photography, and } \\
\text { cleanup. }\end{array}$ \\
\hline 3.4 Biodegradation & $\begin{array}{l}21 \mathrm{~d} \text { each for ASTM G } 21 \text { and } \\
\text { G22 tests on batches of } \\
5 \text { specimens, followed by } \\
\text { compression testing of the } \\
\text { specimens at } 2 \mathrm{~h} / \text { specimen. }\end{array}$ & $\begin{array}{l}15 \mathrm{~h} \text { (batch } \\
\text { of 5) }\end{array}$ & $\begin{array}{l}\text { Labor includes subsequent } \\
\text { compression testing of } 5 \\
\text { specimens, photography, and } \\
\text { cleanup. }\end{array}$ \\
\hline 3.5 Leach Testing & $\begin{array}{l}90 \mathrm{~d} \text { standard, but } 5 \mathrm{~d} \text { for } \\
\text { cementitious waste forms. }\end{array}$ & $\begin{array}{l}60 \mathrm{~h} \text { per batch } \\
\text { of } 3 \text { standard } \\
\text { specimens, } \\
20 \mathrm{~h} \text { per batch } \\
\text { of } 3 \\
\text { cementitious } \\
\text { samples. }\end{array}$ & $\begin{array}{l}\text { Labor includes sampling of } \\
\text { leachates, analysis using NaI } \\
\text { detector, computer reduction of } \\
\text { data, and cleanup as necessary. }\end{array}$ \\
\hline 3.6 Immersion Testing & $90 \mathrm{~d}$ & $\begin{array}{l}20 \mathrm{~h} \text { (batch } \\
\text { of } 5 \text { ) }\end{array}$ & $\begin{array}{l}\text { Labor includes photography and } \\
\text { cleanup, as necessary. }\end{array}$ \\
\hline
\end{tabular}


Table 1b. (continued.)

\begin{tabular}{|c|c|c|c|}
\hline Test & Test Duration & $\begin{array}{c}\text { Labor } \\
\text { (h) }\end{array}$ & Comments \\
\hline $\begin{array}{l}\text { 3.7 Free-standing } \\
\text { Liquid Testing }\end{array}$ & $2 \mathrm{~h}$ & $2 \mathrm{~h}$ & $\begin{array}{l}\text { This test will be conducted by } \\
\text { generator if they prepare full-scale } \\
\text { waste forms. }\end{array}$ \\
\hline 3.8 Full-scale Testing & To be determined & $\begin{array}{l}\text { To be } \\
\text { determined }\end{array}$ & $\begin{array}{l}\text { Full scale testing will be conducted } \\
\text { in a collaboration between BNL } \\
\text { and the generator. Time taken and } \\
\text { work scope to be determined. }\end{array}$ \\
\hline $\begin{array}{l}\text { Final Report } \\
\text { Preparation }\end{array}$ & & $15 \mathrm{~d}$ & $\begin{array}{l}\text { The report will include results and } \\
\text { analyses of all laboratory-scale } \\
\text { tests for a given waste stream, and } \\
\text { include a summary of the ability of } \\
\text { the waste formulation to meet NRC } \\
\text { requirements. }\end{array}$ \\
\hline
\end{tabular}

\subsection{Schedule}

A schedule for completing the work described in the SOW developed in Section 2.2 will be developed. A preliminary estimate of the schedule is presented in Table 2 . Based on the availability of personnel at INEEL or BNL, it is expected that the agreed upon schedule will approximate that shown in Table 2.

\subsection{Conflict of Interest Determination}

An INEEL representative has examined the proposed work on low-level radioactive waste form qualification testing and has determined that it poses no conflict of interest for Lockheed Martin Idaho Technologies Company. A copy of the signed document is shown in Appendix C. However, there are a number of companies that are barred from conducting any kind of business with Lockheed Martin. Therefore, before discussing any possibility of performing this work, it will be determined whether the waste processing company is on that debarred companies list. It is anticipated and hoped that none of the waste processing companies will fall in that category.

\subsection{NEPA Documentation}

A general environmental checklist was prepared, and the NEPA documentation was signed. For each individual project (for a particular waste generator), it will be determined whether there are any deviations from the signed generic NEPA documentation. If such a deviation is determined, required documentation will be prepared. A copy of the signed NEPA documentation is shown in Appendix D. 
Table 2. Preliminary schedule.

\begin{tabular}{c|llllllllll}
\hline Task & \multicolumn{1}{c}{ Month } \\
\hline & 0 & 1 & 2 & 3 & 4 & 5 & 6 & 7 & 8 \\
\hline
\end{tabular}

1. Customer Requirements

1.1 Review requirements

$\Delta-\nabla$

1.2 Coordinate with States

2. Test Plan and Environmental Review

2.1 SOW and Test Plan

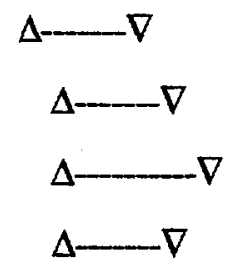

2.3 Waste disposal plan

$-\nabla$

3. Waste Form Tests

3.1 Compression testing

3.2 Thermal cycling

3.3 Irradiation testing

3.4 Biodegradation

3.5 Leach testing

3.6 Immersion testing

3.7 Free standing liquids

3.8 Full scale testing

4. Waste disposal

5. Final Report

6. Facilitate Acceptance of the Report

7. Project Management

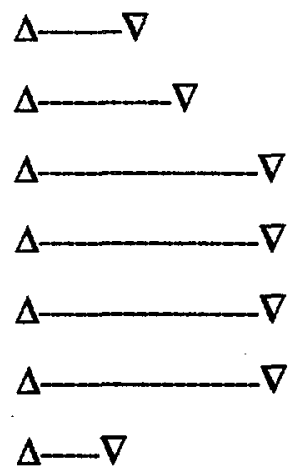

$\Delta-\nabla$

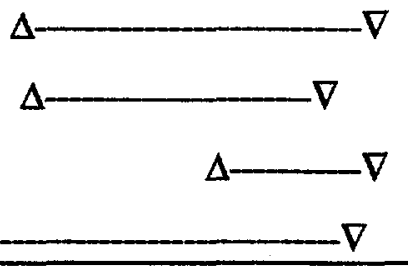

\subsection{Quality Assurance Plan}

For the proposed project, a generic quality assurance plan has been prepared and is given in Appendix E. This plan is similar to the one prepared by Akers et al. ${ }^{13}$ Whenever the proposed testing is about to begin, another specific quality assurance plan will be prepared. It is anticipated that this plan will be adequate for all specific testing projects. A copy of this plan is presented in Appendix E. As a general rule, BNL or any other organization performing the tests under the proposed program as a subcontractor to INEEL, will also abide by the INEEL quality assurance plan. Various states or other similar organizations with vested interest in the waste form testing can also arrange to audit the INEEL QA plan. 


\subsection{Independent Hazard Review}

Before the start of the tests, a generic test plan (an example is given in Appendix F) will be presented to the INEEL Independent Hazard Review Group (IHRG), who will examine the proposed testing from the point of view of health, safety, and other similar regulations. It is anticipated that one generic type approval will be adequate for all individual projects. However if need arises, a specific review for each individual project will be performed. 


\section{WASTE FORM QUALIFICATION TESTING}

The NRC Branch Technical Position on Waste Form summarizes the NRC's regulatory position on waste form qualification. Low-level radioactive wastes are classified as Class A, B, or C, depending on their possible disposal hazard. Class $\mathrm{A}$ wastes are considered the least hazardous and Class $\mathrm{C}$ the most hazardous. Certain minimum requirements must be met by all wastes identified in 10 CFR 61.56(a). ${ }^{2}$ They include basic packaging requirements, prohibition against the disposal of pyrophoric, explosive, toxic and infectious materials, and requirements to solidify or absorb liquids. ${ }^{1}$ Class B and C wastes have the additional requirement that they have "structural integrity" under expected disposal conditions. This will prevent the slumping or collapse of the disposal system and also prevent accelerated release of radionuclides caused by the disintegration of the waste form that could provide an increased surface area for leaching.

Stability for Class B and C wastes is defined by the following conditions stipulated by the Technical Position:

- The waste should be solid or in a container or structure that provides stability after disposal. (The waste form is expected to last for 300 years if it meets the criteria established in the Branch Technical Position. Thus, the high-integrity containers are required by the NRC to have a design life of at least 300 years.)

- The wastes should not contain free-standing or corrosive liquids. That is, the wastes should contain only trace amounts of liquids. When the wastes are placed in a high-integrity container that provides stability, the free liquid must not exceed $1 \%$ by volume of the waste. For solidified wastes, the volume of free liquid must not exceed $0.5 \%$ of the waste volume.

- The waste or container should be resistant to degradation cause by radiation.

- The waste or container should be resistant to biodegradation.

- The waste or container should remain stable under the compressive loads in the disposal environment.

- The waste or container should remain stable if exposed to moisture or water after disposal.

- The as-generated waste should be compatible with the solidification medium or container.

To ensure that waste streams are treated to produce uniform waste forms suitable for disposal, generators or waste treatment process vendors are required to process wastes streams according to a plant-specific process control procedure (PCP) that documents the treatment process for NRC review.

Below are listed the qualification tests that must be performed to judge whether a waste form meets the stability requirements listed in the Technical Position:

- Compression

- Thermal cycling 
- Irradiation

- Biodegradation

- Leach

- Immersion

- Free-standing liquid

- $\quad$ Full-scale waste form.

To minimize costs, simulated, nonradioactive waste samples will be used for the qualification of the waste forms. For leach testing, however, representative radioactive tracers will be used in the specimens, since leaching characteristics can only be accurately tested using radioactive material.

Procedures for these tests are described below.

\subsection{Compression Testing}

\subsubsection{Acceptance Criteria}

Waste forms must have a sufficiently high compressive strength to avoid disintegration from burial stresses and to prevent burial facility slumping. The Technical Position requires a compressive strength of at least 60 pounds per square inch (psi). However, the NRC recommends that generators achieve "maximum practical compressive strength," rather than just the minimum. For cement-based waste forms, the NRC specifies a minimum acceptable compressive strength of 500 psi. This is readily achievable in most cases, since the typical compressive strength of a cementitious waste form is about 5000 psi. $^{3}$

\subsubsection{Testing Methodology}

The compression testing procedure is given in ASTM Standard C39. (In the case of bituminous waste forms, the testing methodology is described in ASTM Standard D1074). ${ }^{5}$ A standard test specimen is a right circular cylinder with a diameter of 2 in. and a length of 4 in. Prior to testing, the ends of the cylinder are "capped" with a suitable nonreacting compound that will provide the parallel end surfaces needed for compression testing. A total of 5 replicate specimens will be tested, and average values of compressive strength and the standard deviation calculated.

\subsection{Thermal Cycling}

\subsubsection{Acceptance Criterion}

Thermal cycling of waste forms will occur only during storage or transportation. Once the waste form is buried, the surrounding temperature will remain essentially constant. However, the NRC believes that thermal cycling should be used as a means of identifying those waste forms that have superior mechanical characteristics. This is based on the fact that many waste forms contain a variety of constituents that have different thermal expansion rates. Since thermal cycling imposes internal 
mechanical stresses, it is assumed that any waste form that resists cracking or spalling during this test possesses superior mechanical integrity.

To be acceptable, "bare" waste forms (no containers) must undergo 30 thermal cycles between $60 \mathrm{EC}$ and $-40 \mathrm{EC}$, and a subsequent compression strength test (ASTM C39) must demonstrate that the compressive strength is at least $60 \mathrm{psi}$. For cementitious waste forms, the strength must be at least 500 psi.

\subsubsection{Testing Methodology}

The thermal cycling procedure will be that given in ASTM B-553, ${ }^{6}$ Section 5.4.1 through 5.4.4. Five replicate specimens will be tested and any spallation or cracking of the waste forms will be documented. The average compressive strength will be determined together with the standard deviation. At least one sample per batch will be checked with a thermocouple to ensure that the temperatures throughout the samples have reached equilibrium before the hold period commences for the two cycling temperatures.

\subsection{Irradiation Testing}

\subsubsection{Acceptance Criteria}

Gamma radiation is usually present in radioactive wastes. It causes ionization damage that may cause gas generation and, also, strength and ductility changes in waste forms. Waste forms must be gamma-irradiated at ambient temperature to at least $10^{8} \mathrm{rad}$, or to a higher maximum value if that is expected for a particular waste form. After irradiation, the waste forms are tested for compressive strength. The strength must be at least $60 \mathrm{psi}$, or at least $500 \mathrm{psi}$ for cementitious waste forms.

\subsubsection{Testing Methodology}

The waste form samples will measure 2 in. in diameter by 4 in. in length. Four specimens will be irradiated in air to a dose of $10^{8} \mathrm{rad}$, at a dose rate of about $10^{6} \mathrm{rad} / \mathrm{h}$, at an ambient temperature of $10 \mathrm{EC}$. Slight gamma heating will occur (10-15EC), but it will have little effect on the irradiation damage process. After irradiation, the samples will be compression tested and the average strength and the standard deviation determined. Values will be compared to those for nonirradiated controls.

\subsection{Biodegradation testing}

\subsubsection{Acceptance Criteria}

Waste forms must be tested for biodegradation (fungal and bacterial) to determine the importance of these types of degradation. The ASTM Standards G21 (fungal) ${ }^{7}$ and G22 (bacterial) ${ }^{8}$ are recommended by the NRC for this purpose. No sign of biodegradation should be observable, and the compressive strength after biodegradation testing should be at least $60 \mathrm{psi}$, or $500 \mathrm{psi}$ for cementitious waste forms. 


\subsubsection{Testing Methodology}

In the ASTM G21 test, waste forms measuring $2 \mathrm{in}$. in diameter and $4 \mathrm{in.}$ in length are exposed to a mixture of 5 different types of fungi. Five tests specimens are placed in contact with a nutrient-salts agar mixture contained in a sterile dish. A suspension of the fungal inoculant will be sprayed onto the agar and the sample surfaces which will be maintained at $28-30 \mathrm{EC}$, at $85 \%$ relative humidity, for 21 days. They will be checked periodically for fungal growth.

In the G22 tests, 5 samples will be placed on the nutrient-salt agar and sprayed with the bacterium Pseudomonas aeruginosa. The samples will be maintained at 35-37EC, at 85\% relative humidity, for 21 days. Periodically, they will be examined for bacterial growth.

After the G21 and G22 tests, the specimens will be tested to determine whether they meet the compressive strength requirements described above.

\subsection{Leach Testing}

\subsubsection{Acceptance Criteria}

Leach testing of waste forms is undertaken to demonstrate that releases offsite due to contact with groundwater are within prescribed limits. The limit is given as a leachability index $(L)$, which is the logarithm of the effective diffusivity of each radionuclide of interest. A waste form has an acceptable leachability if $L$ is greater than 6 .

\subsubsection{Testing Methodology}

The ANSU/AND 16.1 standard is the leaching procedure specified in the Branch Technical Position. ${ }^{9}$ Three specimens per waste form are to be tested. They will measure 2 in. in diameter by 4 in. in length. Leaching will be performed for a period of 90 days, except for cementitious samples, which will be leach tested for 5 days. Deionized water or synthetic seawater is normally used for the leachant, depending on which is shown from preliminary testing to produce the highest leach rate. This will ensure that conservative leachability indices are measured.

\subsection{Immersion Testing}

\subsubsection{Acceptance Criteria}

Immersion testing in either deionized water or synthetic seawater will be carried out to determine if a waste form maintains its structural integrity after burial. Short term tests will be initially carried out to determine the most aggressive immersion medium before one or the other is selected for the 90-day immersion tests. Specimens will be cured for 28 days before testing commences.

\subsubsection{Testing Methodology}

Five specimens per waste form will be tested. During the immersion period, they will be visually inspected for evidence of cracking, spalling, or disintegration. If there are no significant immersion effects, the waste forms will be compression tested, as described above. The waste forms should have a compressive strength of at least $60 \mathrm{psi}$, except for cementitious waste form, which must have a strength 
of at least 500 psi, but not less than $75 \%$ of the preimmersion value. If the average postimmersion compressive strength for cementitious samples is less that $75 \%$ of the preimmersion value, additional samples from the same batch will be immersion tested for an extended period of 180 days total to ensure that the long-term strength does not continue to decline with time.

For certain types of waste stream (namely resin beads, chelates, filter sludge, and floor drain wastes) additional immersion tests will be carried out because they have been shown to exhibit complex behavior. ${ }^{10}$ Such specimens will be cured for 180 days in sealed containers. The immersion period will be for 7 days, followed by drying in ambient air at a minimum temperature of 20EC for another 7 days. After drying, the samples will be visually inspected for cracking or spalling, and then compression tested as described above. The average compressive strength and the standard deviation will be determined.

\subsection{Free-standing Liquid Testing}

\subsubsection{Acceptance Criteria}

Excessive amounts of free standing liquids in contact with waste forms and their containers must be avoided to minimize the release of contaminants and container corrosion. The amount of liquid must not exceed $1 \%$ of the waste volume if the waste is placed in a high-integrity container, and less than $0.5 \%$ of the waste volume for other containers. The $\mathrm{pH}$ of the liquid must be between 4 and 11, except for cementitious waste forms, for which the liquid $\mathrm{pH}$ must be at least 9 .

\subsubsection{Testing Methodology}

The ANS 55.1 methodology ${ }^{11}$ will be used to measure the amount of free-standing liquid. A suitable $\mathrm{pH}$ probe will be used to measure the $\mathrm{pH}$ of any free liquid.

\subsection{Full-scale Testing}

To ensure that laboratory-scale tests reflect the behavior of full-scale forms, actual prototype waste forms will be prepared. For each type of waste stream, two full-scale waste forms will be prepared by the vendor using procedures and equipment typical of that to be used in the field. Triplicate samples ( 2 in. in diameter by 2 in. in length) will be removed from selected locations of each waste form by sectioning or coring. Assuming that the waste forms are of 55-gallon drum size, the samples will be taken from the center and outer regions of the cylindrical forms at locations $1 / 3$ and $2 / 3$ from the bottom of the forms. This will give four testing locations, with 3 samples per location for each waste form.

The following tests will be performed to check the integrity of the full-scale waste forms:

1. Perform compression tests on the samples after they have been cured for at least 28 days, to determine whether they are similar to those for the laboratory-scale samples

2. Perform 90-day immersion tests followed by compression testing, to determine that the fullscale waste form gives similar results to the laboratory-scale samples

3. Check the samples destructively and compare them to determine whether there is homogeneity within the original full-scale waste form. 


\section{WORK SCHEDULES, QUALITY ASSURANCE, AND COSTS}

Table 1 briefly outlines the times for the various tests and the associated labor. Once the data have been acquired for the suite of tests for a given waste stream, a final report will be prepared. This will take, on average, a period of three weeks to complete. It will include data analysis, preparation of graphics, and a complete description of the testing procedures. All quality assurance will meet the Appendix B of $10 \mathrm{CFR} 50^{12}$ requirements. It will involve documentation, equipment calibration, worker qualification, etc.

The work will be carried out by qualified staff of either INEEL or BNL. Since the hourly support costs for the staff may vary and may be subject to changes, a detailed cost estimate for work performed will be developed at the time of testing.

For irradiation testing at BNL, only two standard waste forms can be accommodated per irradiation cycle, so this will entail two separate irradiations for a given waste batch of 4 . Each irradiation cycle will cost $\$ 5 \mathrm{~K}$. However, all samples can be accommodated in a single batch at the INEEL.

In all cases, it is noted whether the test will be performed on radioactive or nonradioactive samples as the cost may vary significantly based on this characteristic. Table 1 lists the tasks to be performed, the expected number of labor hours, and comments on the test. Table 2 lists the duration of various tasks and when specific tests would be expected to begin and end from a given start date. It is also assumed that existing equipment such as the furnace for thermal cycling and required laboratory equipment is usable and available. In addition, some initial startup costs, such as preliminary tests of the thermal cycling furnace, have not been included as these costs should not be costed to a single customer, but to the Program or to several customers.

This overall cost reflects a significant emphasis placed on quality assurance, and it will be the first time that the integrated test program is performed in the current regulatory environment. For most tests, including compression, leaching, and full-scale waste form testing, a number of quality assurance standards and samples will be obtained and analyzed to ensure quality data. In addition, emphasis has been placed on a well-defined test plan with appropriate quality assurance requirements. These results will ensure that the data are accurate and will meet NRC requirements. 


\section{POST-TEST ACTIVITIES}

After completing all the tests, it is anticipated that the INEEL will facilitate review and acceptance of the test reports with: (1) the Host State Technical Coordinating Committee; and (2) the Conference of Radiation Control Program Directors. The states that have disposal facilities are represented on these two groups. The objective of this coordination is that the waste forms meet the regulations for disposal and safe long-term isolation of the waste will contribute to the public health and safety. Review and acceptance of the test reports will directly benefit the states and therefore, is a part of the National LowLevel Waste Management Program under the Low-Level Radioactive Waste Policy Amendments Act of 1985 (Public Law 99-240). Thus, facilitation of the test results with the above two groups will be paid out of the State's Technical Assistance Program. It is hoped that once the test report has been reviewed and accepted by these two groups, states will find it easier to accept the reports. Thus, this testing process will contribute effectively towards continued waste isolation. 


\section{CONCLUSIONS}

The objective of the proposed work is to develop a low-level waste testing process that becomes equally acceptable to various interested organizations, that is, the waste generators, waste processors, and the states that are candidates for accepting redioactive waste for deposition. It should also serve the function of the now defunct NRC process of reviewing the test reports on low-level waste testing.

The INEEL has completed most of the preliminary work needed to initiate a waste testing process. Most of the administrative and procedural matters have been either completed or are in progress. A protocol for the benefit of those willing to use this testing service is provided in Table 3. INEEL is in the process of developing similar testing plan for high-integrity containers and macro-encapsulation waste forms. Preliminary work to prepare the laboratory setup to start the tests has begun. Comments to improve the testing system are welcome. 
Table 3: Protocol for Low-Level Y

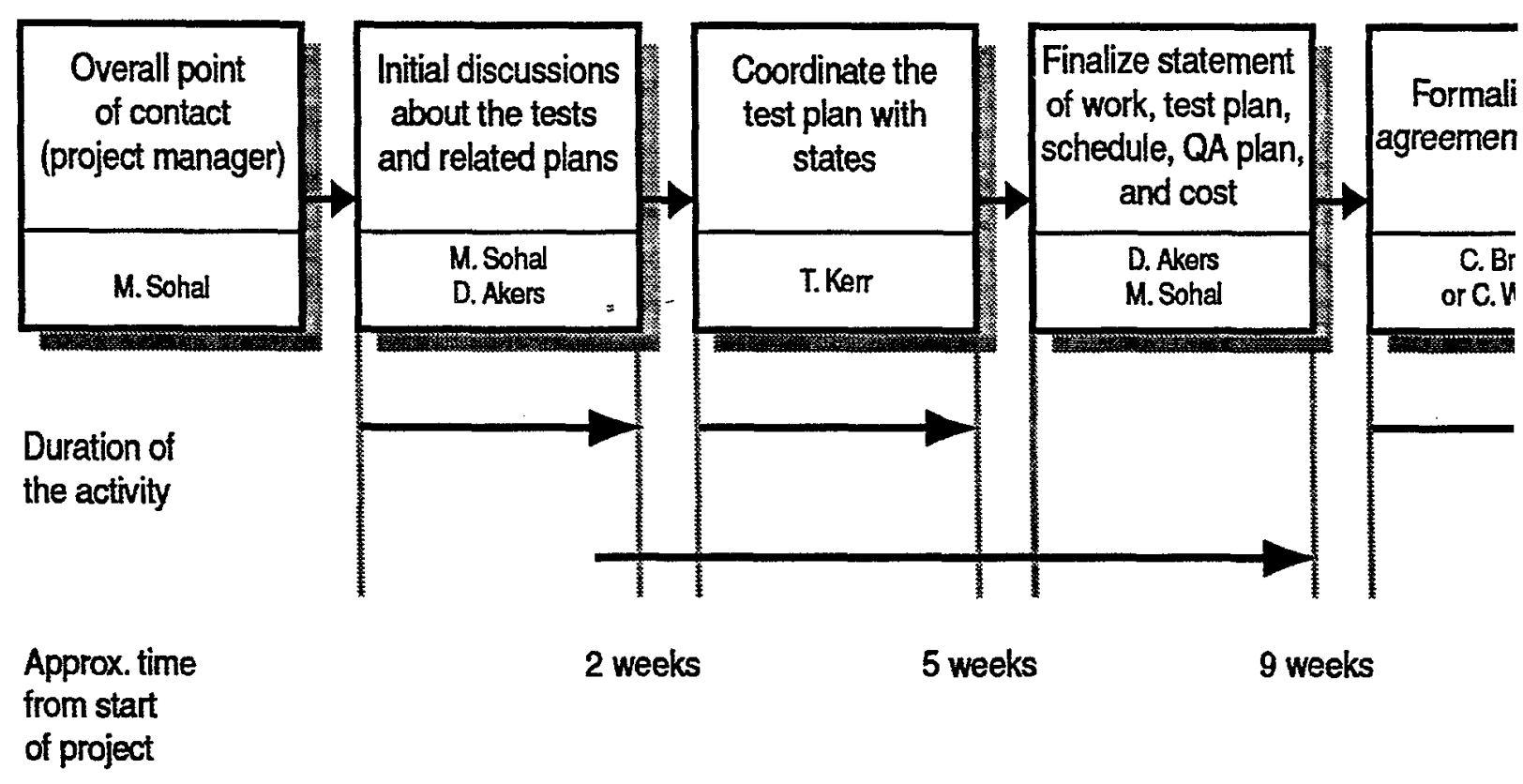

Name

Manohar S Sohal

Doug W. Akers

Thomas A. Kerr

Charles W. Briggs

Cindy F. Willins 


\section{aste Form Qualification Testing}

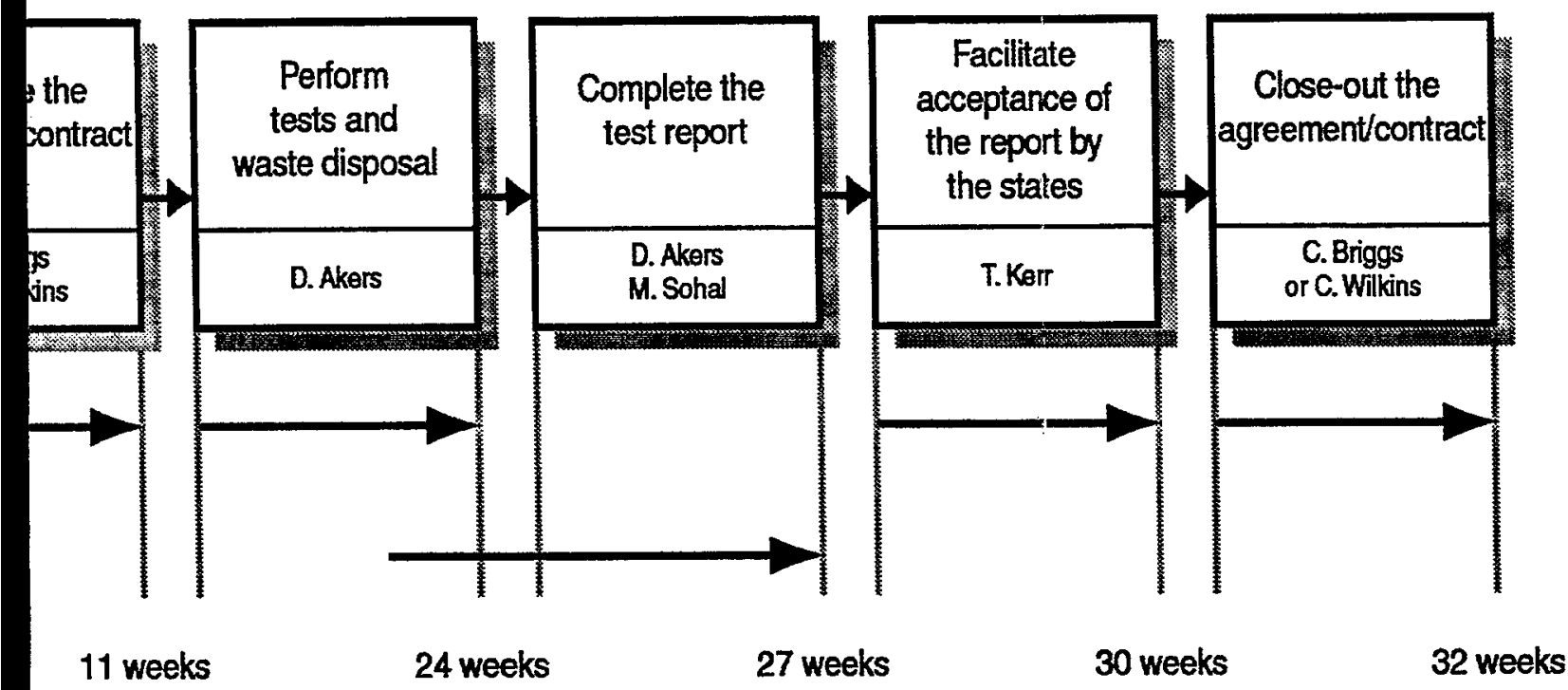

\begin{tabular}{|c|c|c|c|c|}
\hline Phone & Fax & E-mail & Mail Stop & \\
\hline (208) 526-9412 & (208) 526-8883 & sohalma inel.gor & 3815 & Mailing Address: \\
\hline (0) $526-6118$ & (208) 526-9267 & dwa einel.gov & 2114 & $\begin{array}{l}\text { Name } \\
\text { Lockheed Martin Idaho Technologies Co. }\end{array}$ \\
\hline 88) $526-8465$ & (208) 526-8165 & tak@inel.gor & 2420 & Idaho National Engineering and Environmental Laboratory \\
\hline 8) $526-0441$ & (208) 526-0876 & cwbeinel.gor & 3805 & Idaho Falls, ID 83415-Mail Stop \\
\hline 3) $526-0066$ & (208) 526-5561 & cfw@inel.gov & 3200 & \\
\hline
\end{tabular}

$M 980192$ 


\section{REFERENCES}

1. "Technical Position on Waste Form (Revision 1)," Nuclear Regulatory Commission, January 1991.

2. Licensing Requirements for Land Disposal of Radioactive Waste," Code of Federal Regulations 10 CFR Part 61.

3. Workshop on Cement Stabilization of Low-level Radioactive Waste, NUREG/CP-0103, NRC, 1989.

4. American Society for Testing and Materials Standard Test Method for Compressive Strength of Cylindrical Concrete Specimens, ASTM C39, October 1984.

5. American Society for Testing and Materials Standard Test for Compression Strength of Bituminous Mixtures, ASTM D1074, 1980.

6. American Society for Testing and Materials Standard Test for the Thermal Cycling of Electroplated Plastics, ASTM B553, 1979.

7. American Society for Testing and Materials Standard Test for Determining Resistance of Synthetic Polymeric Materials to Fungi, ASTM G21, 1970.

8. American Society for Testing and Materials Standard Test for Determining Resistance of Plastics to Bacteria, ASTM G22, 1976.

9. Measurement of the Leachability of Solidified Low-level Radioactive Wastes by a Short-term Test Procedure, ANSI/ANS Standard 16.1, American National Standards Institute/American Nuclear Society, 1988.

10. P. L. Piciulo et al., The Effect of Cure Conditions on the Stability of Cement Waste Forms After Immersion in Water, Brookhaven National Laboratory Report WM-3171-4, 1987.

11. "Solid Radioactive Waste Processing System for Light Water Cooled reactor Plants, Appendix 2," ANSI/ANS Standard 55.1, American National Standards Institute/American Nuclear Society, 1979.

12. "Licensing of Production and Utilization Facilities," Code of Federal Regulations 10 CFR Part 50.

13. D. W. Akers, C. A. Dicke, and D. A. Johnson, Subsurface Contaminant Soil/Water Partition $\left(K_{d}\right)$ Assessment Quality Assurance Program Plan, Idaho National Engineering Laboratory Report INEL-96/318, January 1997. 
Appendix A DOE Approval 


\section{Department of Energy \\ Idaho Operations Office \\ 850 Energy Drive \\ Idaho Falls, Idaho $83401-1563$}

August 21, 1996

Cindy Wilkins

Lockheed Idaho Technologies Company

P.O. Box 1625

775 Lindsay Boulevard

Idaho Falls, ID 83415-3560

SUBJECT: Waste Form Container Qualification Reports - Umbrella Agreement - WFO Project \# 96832 - (LD-WFO-96-174)

Dear Ms. Wilkins:

The Department of Energy, Idaho Operations Office, (DOE-ID), has reviewed and endorses the decision package for the subject project. You are authorized to proceed with negotiations for a contract on the above mentioned project.

Copies of all funding documents shall be provided to $\mathrm{K}$. H. Reynolds and A. C. Wynn. Signed copies of all final agreements shall be provided to A. C. Wynn.

Sincerely,

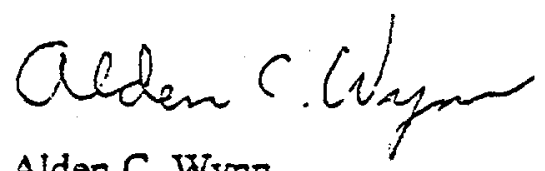

Alden C. Wynn

Work-for-Others Coordinator

Approved:

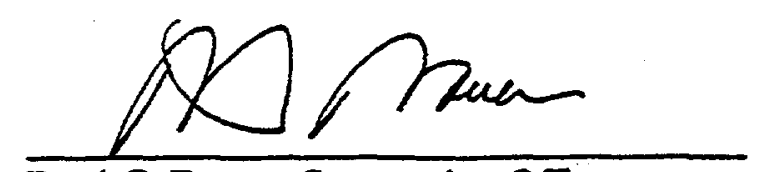

Brad G. Bauer, Contracting Officer 
EXTERNAL bCc DISTRBBUTION:

J. L. Lytie, LITCO, MS 3805

DDISTRBUTION:

CONCURRENCE:

J. G. Snook, MS 1136

\section{RECORD NOTES:}

1. This letter was written to authorize C. Wilkins of LITCO to start negotiations with the sponsor on a contract for project \# 96832.

2. No coordination required at this time.

3. This letter/memo closes CATS number N/A

4. The attached correspondence has no relation to the Naval Nuclear Propulsion Program. Naval Reactors concurrence is not required.

A. C. Wynn (LD): nkcrane, 6-7863,August 21, 1996, a:WWKNNS.174 


\section{Appendix B}

Work-for-Others Cost Form 


\begin{tabular}{|l|l|l|l|}
\hline 1. Customer/Address: & 2. Project Number: & 3. WFo Control Number: & 4. Mod. No.: \\
\hline 5. Project Title: & 6. Original Source of Funding: \\
\hline 7. Customer Technical Representative: & Telephone: \\
\hline 8. DOE-ID Technical Contact: & Telephone: \\
\hline 9. Performing Organization's Program Controls Signature \& Date: & 10. General Accounting Signature \& Date: \\
\hline
\end{tabular}

11. Scope of Work - Title:

12. Technical Performer:

Ext.:

Date:
13. Technical Manager:

Ext.:

Date:

\section{Approval Signature}

15. Total Cost Estimate (If sales tax applied)

17. Period of Performance:

16. Total Cost Estimate (If no sales tax applied) $\$$ Notes: 


\begin{tabular}{|l|l|l|l|}
\hline 1. Customer: & 2. Project Number: & 3. WFO Control Number: & 4: Mod. No.: \\
\hline
\end{tabular}

A. Labor (Cost Element G)

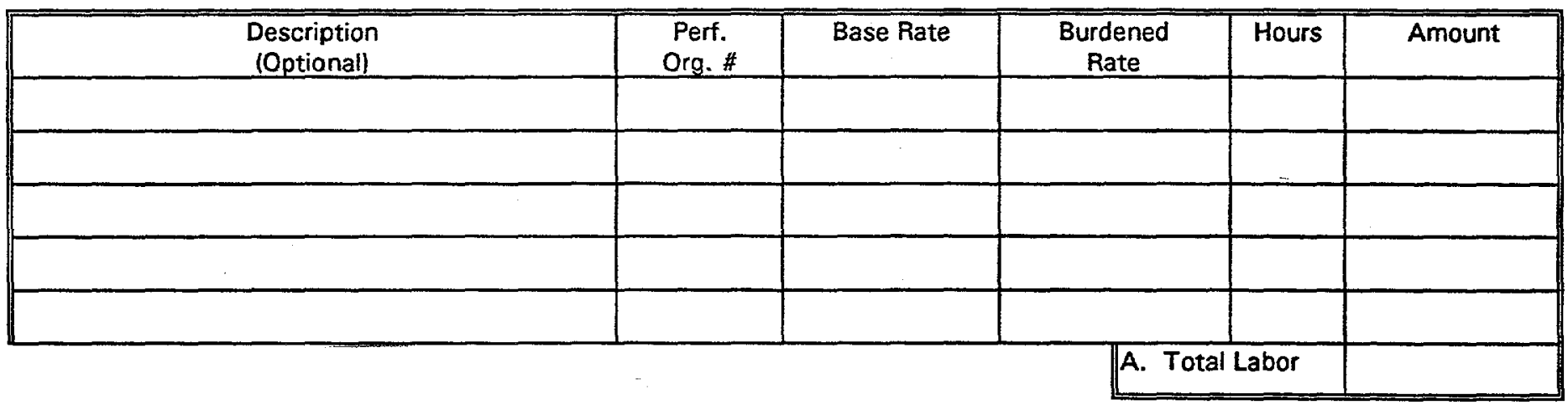

\section{B. Material (Cost Element M)}

\begin{tabular}{|c|c|c|c|c|c|}
\hline \multirow[t]{2}{*}{ Description } & \multirow[t]{2}{*}{ Cost Elem. } & \multirow{2}{*}{$\begin{array}{l}\text { Material } \\
\text { Amount } \\
\end{array}$} & \multicolumn{3}{|c|}{ Material Handling (M9) } \\
\hline & & & Sales Tax * & $\mathrm{MH} \%$ & MH Amount \\
\hline & & & & & \\
\hline & & & & & \\
\hline & & & & & \\
\hline & & & & & \\
\hline & & & & & \\
\hline & Subtotal Mat & Amount & & & \\
\hline & $\begin{array}{l}\text { Subtotal Tax } \\
\text { Applied) }\end{array}$ & A Not & & & \\
\hline & Subtotal Mat & Handling & & & \\
\hline & G\&A on Mat & and Handling & & & \\
\hline & B. Total Mo & & & & \\
\hline
\end{tabular}

C. Travel (J)

- Contact General Accounting for Determination of Sales Tax Applicability.

(1) Travel Expenses

\begin{tabular}{|l|l|l|l|l|l|l|}
\hline Airfare & Per Diem & Lodging & Car Rental & Other & \\
\hline & & & & & \\
\hline & & & & & \\
\hline & & & & Subtotal Travel \\
\hline
\end{tabular}


\begin{tabular}{|l|l|l|l|}
\hline 1. Customer: & 2. Project Number: & 3. WFO Control Number: & 4. Mod. No.: \\
\hline
\end{tabular}

\section{(2) Temporary Assignment Destination}

\begin{tabular}{||l|l|l|l|l|l|}
\hline \multicolumn{2}{|c|}{ Description } & \multicolumn{2}{c|}{ Count } & \multicolumn{1}{l|}{ Rate } & \\
\hline Travel to New Assignment (J): & Miles & & & \\
\hline Air Fare & Nights & & & \\
\hline $\begin{array}{l}\text { Personal } \\
\text { Car }\end{array}$ & Days & & & \\
\hline Lodging & Days & & & \\
\hline Meals & Days & & & \\
\hline Interim Living Expenses & Days & & & \\
\hline $\begin{array}{l}\text { Per Diem } \\
\text { (P5) }\end{array}$ & Trips & & & \\
\hline Home Visits (P5) & & & \\
\hline Travel at End of Assignment (J) & Miles & & & \\
\hline Air Fare & Nights & & & \\
\hline $\begin{array}{l}\text { Personal } \\
\text { Car }\end{array}$ & Days & & & \\
\hline Lodging & Days & & & \\
\hline Meals & (2) Subtotal Temp. Assignment Costs & \\
\hline
\end{tabular}

(3) Permanent Assignment: Attach schedule showing cost details

(3) Subtotal Permanent Assignment Costs

(4) Subtotal Items (1) and (2)

(5) G\&A on Item (4)

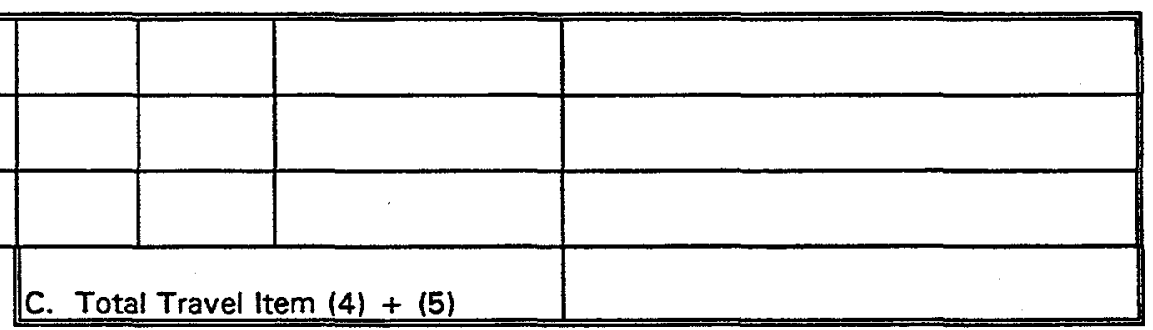

D. Other Costs

\begin{tabular}{|l|l|l|l|}
\hline & Cost Elem. & \\
\hline & & & \\
\hline & & & \\
\hline & & & \\
\hline & & & \\
\hline & Subtotal Other Costs & \\
\hline G\&A on Other Cost (T1) & \\
\hline D. Total Other Costs & \\
\hline
\end{tabular}




\begin{tabular}{|l|l|l|l|}
\hline 1. Customer: & 2. Project Number: & 3. WFo Control Number: & 4. Mod. No.: \\
\hline
\end{tabular}

E. Proposal/Project Plan Preparation Costs

\begin{tabular}{|c|c|c|c|c|}
\hline Perf. Org. & Hours & $\begin{array}{c}\text { Labor \& } \\
\text { Associated Dollars }\end{array}$ & Material Dollars & Amount \\
\hline & & & & \\
\hline & & & Total Dollars & \\
\hline
\end{tabular}

\section{F. Management Reserve (Optional}

\section{Explanation:}

\section{G. Subtotal Items A Through F}

Charges of Depreciation applied to Subtotal G. Added Factor applied to Subtotal G and Depreciation. Depreciation and Added Factor applied to Non-Federal WFO agreements unless waivers are applied for and granted. (Item H/I)

NOTE: The DOE Added Factor (Item J) applies only to other Federal Agencies.

H. Depreciation $(8.5 \%$ site) $(1.5 \%$ town $)(0 \%$ outplant) Non-Federal

1. Added Factor $(12.4 \%)$ Non-Federal

J. DOE Added Factor (4.3\%) Other Federal Agencies

K. Total Items (G, H, and I) or (G and J) (Transfer Total Cost Estimate to Page 1, Line 15 or 16)

Waiver Requested? $\square$ Yes $\square$ No


Appendix C

\section{Conflict-of-Interest Determination}




\section{WORK FOR OTHERS \\ ORGAYIZATIONAI CONFLICTS OF INTEREST ASSESSIMENT}

FORM L-0481.16\#

(03-96 - Rev. $\$ 00)$

Proposal Number:

96832

Date: $222-26$

Complete the foilowing checklist :

1. Does the proposed work include any services or products that may be used in a furure competitive procurement process to be conducted by, or for, the sponsor?

2. Does the proposed work indicate that the INEI will perform any of the following activities at the request of the Government agency for a competitive government procurement process? (ff Yes, please check any applicable activities below.)

drafting a specification or staternent of work review and approval of a specification development of procurement or purchase request preparation or issuance of a solicitation

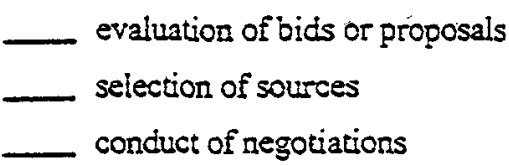
review and/or approval of a contract or contract YES NO modification

3. Does the INEI or the Government agency know that any Lockheed Martin (LM) operating unit has, or might in the furture have an interest in competing on a government procurement relating to or resulting from the INEL's work on this project?

(Please respond to question 3 conservatively, using facts that you know or that you have obtained from the Government agency sponsor. "Don't Krow" is an acceptable answer.)

4. Check ONE appropriate statement below.

NO OCI POTENTLAL If answers to questions 1 and 2 are NO, then skip question 5 and sign below.

EXPLANATION If answers to questions 1 or 2 are YES, and anstrer to question 3 is NO, than attach an explanation to this form, skip question 5 and sign below.

In the attachment to this form briefly explain your detemination that LM operating units do not have an interest in competing on the government procurement related or resulting from the $\mathbb{N} E$ I's work on this project (E.g., market knowledige, sponsor's knowledge, etc.) No OCI statenent is required in the SOW.] OCI ISSUE —- If answers to questions 1 or 2 are YES, and answer to question 3 is YES or don't know, contact the LTTCO OCI Coordinator, 526-6206 or LITCO WFO Coordinator, 526-1492 for assistance prior to completing question 5 and providing any additional information.

5. Discuss the INEI's WFO OCI awareness, mitigation, and resolution process with your sponsor. After discussion with your sponsor, check the appropriate box below, inplement the activity indicated, and sign below.

CLAUSE _ OCI Management Clause is incorporated in the Statement of Work. PLAN OCI Management Plan is attached to the Statement of Work.

RESOLUTION _- Sponsor bas deternined that OCI Managenent Clause or Plan is not acceptable and bas specified an $\mathrm{OCI}$ resolution as described in the attachment

(In the attachment to this form explain the sponsor's rationale in determining that an OCI Management Clause or Plan is not acceptable. Describe the OCI resolution that is acceptable to the sponsor.)

Approved by:

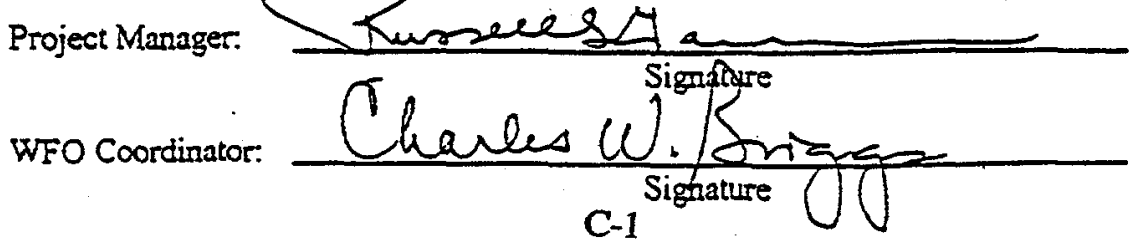

Date:

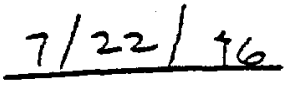

Date:

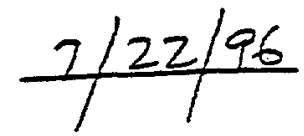


Appendix D

NEPA Documentation 


\section{NEPA Document Approval Form}

Projoet Na: $\quad$ NELL-96-030

Project Title: Waste Form and Container Qualification Repors - Umbrella Agreegreat

The undersigned agree that the inforwation in the above-referenced document is true, sccurate, and complete to the best of their knowledge. The condition below must be completed before commencing follow-on activities. This listing is not intended to be a listing of cnvironmental requirenents that must be met while conducting the setivity. The facility Environmental Support representative should be consteted to determine any additional enviroomental requirenents.

Condition:

Avy receipt, handling, analysis, or besting of wastes, products, or trestments st the REL would requirs the subruittal and approval of s specifio environeneatal obecklist prior to commencenest of the sctivity.

IMATCO:

Signature:

Author:

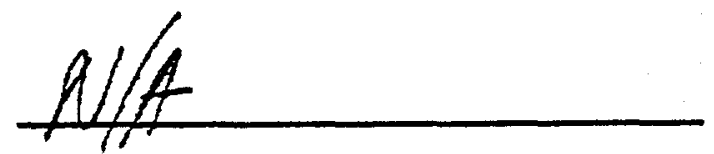

Tectuical Rovietrer.

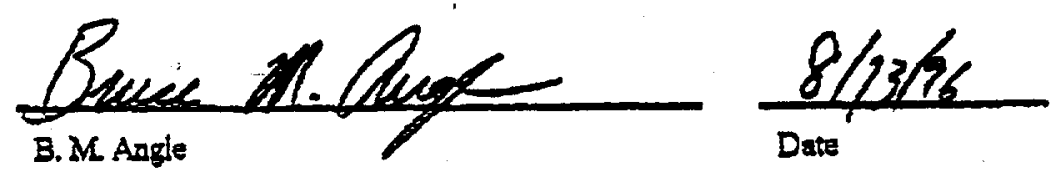

Project Marager:

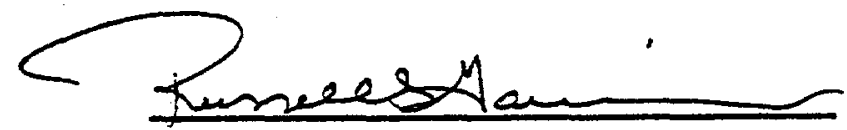

Rusgíle

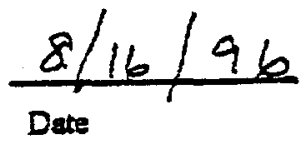

Facility Operations Manager:

N/A

NEPAPermining

Departenent Manggers.

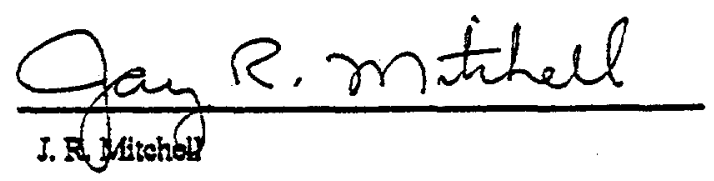

$8 / 19 / 96$

Date 
NOTE: THIS FORM CANNOT BE MODIFIED FROM THE ORIGINAL DESIGN IN AVY WAY. Use the arrow keys to maneuver through this form Using the tab key will insert rows at the end of the document.

DIRECTIONS: Section A through $D$ to be completed by the progran/project manager. Sections $E$ \& $F$ to be completed by the appropriate Contractor Eavironmental Organization (CEO), the DOE-ID NEPA Compliance Officer (NCO), or as indicated.

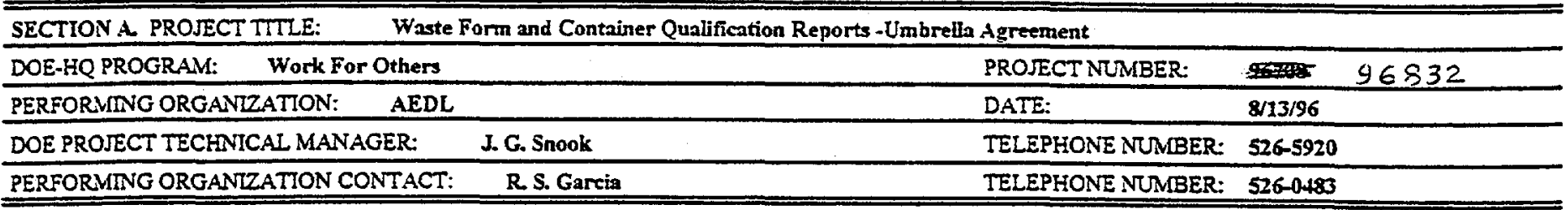

SECTION B. Project Description: Attach a complete and concise description of the project or action, including type of action (e.g., new construction, process modification, maintenance, new activity, research and development, or work for others), purpose and needi, pollution prevention and waste minimization measures, projected stant and end dates, and approximate cost.

SECTION C. Sources of Impact: Would the action involve, generate, or result in changes to any of the following? (If yes, explain on attachment)

\begin{tabular}{|c|c|c|c|c|c|c|c|}
\hline Source & Yes & No & Source & Yes & Source & Yes & No \\
\hline 1. Air Emissions & & $\mathbf{x}$ & 8. Water/Well Use & $\mathbf{x}$ & 15. Hazardous Waste & & $\mathbf{x}$ \\
\hline 2. Asbertos & & $\mathbf{x}$ & 9. Wattr Course Modification & $\mathbf{x}$ & 16. Radioactive Waste & & $\mathbf{x}$ \\
\hline 3. Work Force Adjustment & & $\mathbf{X}$ & 10. Pesticide Use & $\mathbf{X}$ & 17. Mixed Waste & & $\mathbf{x}$ \\
\hline 4. Excess Noise Levels & & $\mathbf{x}$ & 11. Chemical Use/Storage & $\mathbf{x}$ & 18. Radiation Exposure & & $\mathbf{x}$ \\
\hline 5. Utility Modification & & $\mathbf{x}$ & 12. Petroleum Storage & $\mathbf{x}$ & 19. Liquid Effluent & & $\mathbf{x}$ \\
\hline 6. Soil Disturbance & & $\mathbf{x}$ & 13. Solid Waste & $\mathbf{x}$ & 20. Sensitive Resources & & $\mathbf{x}$ \\
\hline 7. Water Treatment & & $\mathbf{x}$ & 14. PCBs & $\mathbf{x}$ & 21. CERCLARCRA Site & & $\mathbf{x}$ \\
\hline
\end{tabular}

SECTION $D$. The action is determined as: (check one of the following)

X] Appeadir A Actions

Applicable Appendix A CX section: $\mathrm{HS} \& \mathrm{HII}$

Appendix A Projest Manager Sigrature:

DOE-ID Approved CX: INEL-95-012

Routine Maintenance (RM)

Applicable RM CX section:

Certified RM Reviewer Signature:

DOE-ID Approved CX: INEL-95-018

If RM, complete Section $\mathbf{E}$.

Further NEPA documentation is required. Forward to appropriate CEO for NEPA document number and determination. *********************TO BE FILLED OUT BY THE CONTRACTOR ENVIRONMENTAL ORGAVIZATION**********************

SECTION E. Category Evaluation Criteria: Would the action... (If yes, explain on attactument.)

1. Require cuitural, historical, or biological clearances?

2. Potentially inpact sensitive resources identified in ltem 1 above. Describe the mitigation plan

3. Require or modify federal state, or local permits, approvais, ete?

4. Be inconsistent with any existing consent orders or agreements (i.e., FFA-CO, site wide treatment plans, etc.)?

5. Create hazandous, madioactive, PCB, or mixed waste for which no disposal is available?

6. Require siting construction, or modifieation of a RCRA or TSCA regulated facility?

\begin{tabular}{|c|c|}
\hline Yes & No \\
\hline & $x$ \\
\hline & $X$ \\
\hline & $X$ \\
\hline & $X$ \\
\hline & $X$ \\
\hline & $X$ \\
\hline
\end{tabular}

SECTION F. NEPA level of documentation and refereace(s).
CX: $X$ EA:
EIS:
Previously Approved NEPA Documents:
Not Covered in 10 CFR 1021:

Reference(s): Covered under DOE NEPA Rules and Regulation s, 10 CFR 1021, Section A to Subpart D, CX A9, Information gathering data analysis document preparation/ discemination, and CX All, Tecturical advice and assistance to organizations

The proposed action would not: 1) threaten a violation of applicable statutory, regulatory, or permit requirements for enviranaental, safety, and bealth, including requirements of DOE orders; 2) require siting and construction or major expansion of waste storage, disposal, recovery, or treatiment facifities; 3) disturb hazardous substances, pollutants, contaminants, or CDRCLA-exchuded petroleum and natural gas products that pre-exist in the environanent such that there would be uncoutrolled or

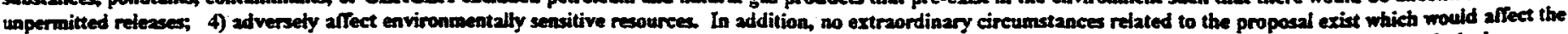
sigaificance of the action, and the action is not "connected" nor "reiated" (40 CFR 1508.25(a)(1) and (2), respectiveb) to other actions with potentially or cumulatively significant impacts

Name: Bruce M.Angle

Signature:

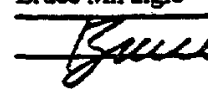

Telephone No.: 526-1841

Date: August 13, 1996 


\section{ENVTRONMENTAL CHECKLIST \\ U.S. DEPARTMENT OF ENERGY \\ IDAHO OPERATIONS OFFICE}

\section{ENVIRONMENTAL CHECKIIST ATTACHMENT}

\section{SECTION B (con't). PROJECT DESCRIPTION:}

As described in the attached letter from C. W. Briggs to A. C. Wynn, WFO-25-96

The proposed activity covers the paperwork aspects of certifying specific products and treatments for dealing with low-level radioactive waste. Based on waste and product characteristics and other information provided by other parties, the project will determine an appropriate course of analyses and studies to certify the product or treatment and prepare a report. Additionally, the project will direct certain analyses which would be contracted out to other laboratories including other recognized national laboratories.

Any receipt, handling, analysis, or testing of wastes, products, or treatments at the INEL would require the submittal of a specific environmental checklist.

\section{CONDITIONS:}

1. Any receipt, handling, analysis, or testing of wastes, products, or treatments at the INEL would require the submittal and approval of a specific environmental checklist prior to commencement of the activity.

\section{CONTRACTOR COMMENTS:}

The proposed program encompasses administrative activities involving only information gathering, data analysis, document preparation and dissemination, and providing technical advice. These administrative activities are categorically excluded under Appendix $A$ to Subpart D of the DOE NEPA Regulations (10 CFR 1021). However, as a result of the activities performed under this program, there is a potential for analytical studies to be performed at the INEL and for samples of wastes, products, and other materials to be brought to the INEL. Any such activities, beyond the administrative activities encompassed by this environmental checklist, would require the submittal and approval of specific environmental checklists prior to the commencement of the activities. 
Appendix E

Quality Assurance Plan 


\title{
NRC Branch Technical Position Test Program Quality Assurance Program Plan
}

\author{
Draft
}

D. W. Akers

Published October 1997

Idaho National Engineering and Environmental Laboratory

Lockheed Martin Idaho Technologies Company

Idaho Falls, Idaho 83415

Prepared for the

U.S. Department of Energy

Assistant Secretary for Environmental Management

Under DOE Idaho Operations Office

Contract DE-AC07-94ID13223 



\title{
NRC Branch Technical Position Test Program Quality Assurance Program Plan
}

\author{
Revision 0
}

Approved by:

Program Manager

Date:

Date:

Principle Investigator

Approved by:

QA Officer

Date:

Date:

Date:

Reviewed by:

Date:

Prepared by: 


\begin{abstract}
The Quality Assurance Program Plan (QAPP) for the NRC Branch Technical Position Test Program provides the requirements and guidance for this project as defined in the Test Plan for this project. The QAPP specifies the quality requirements to ensure the validity of the data obtained as defined in the test plan for this project. The QAPP also identifies data requirements; specific data quality objectives; test system design requirements; and the sampling, measurement, and analysis methods to be used per the test plan.
\end{abstract}




\section{CONTENTS}

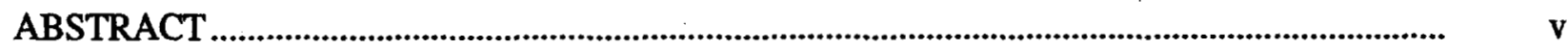

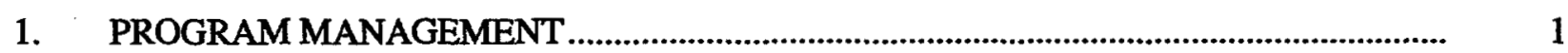

$1.1 \quad$ Problem Definition and Background.............................................................. 1

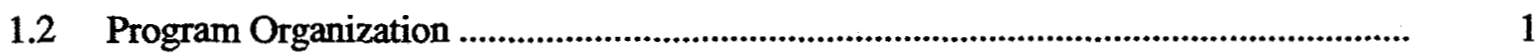

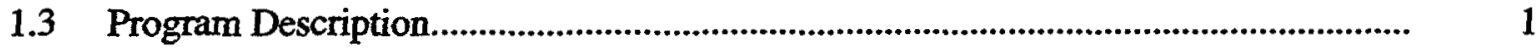

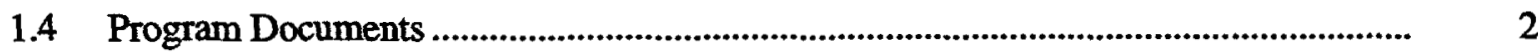

1.4.1 Quality Assurance Program Plan ........................................................................ 2

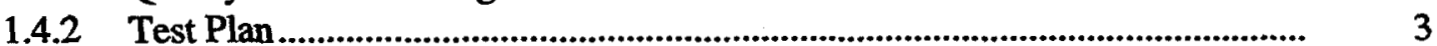

1.4.3 Document Review, Approval, and Control .................................................. 3

1.5 Data Quality Objectives for Measurement Data ...................................................... 3

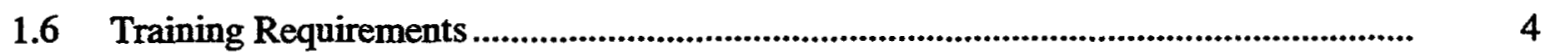

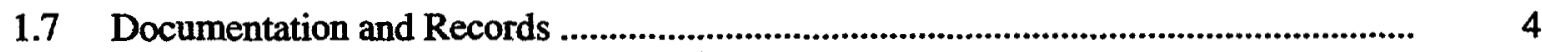

1.7.1 Laboratory Notebook ............................................................................... 5

1.7.2 Final Data Package ............................................................................ 5

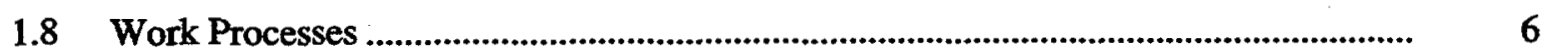

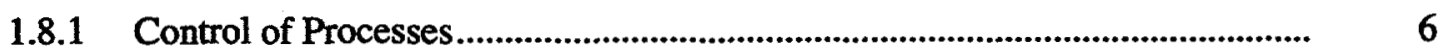

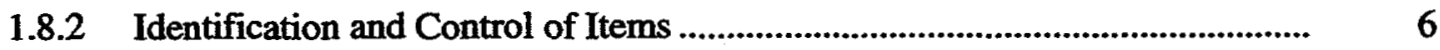

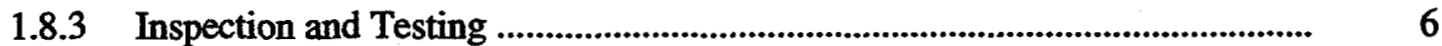

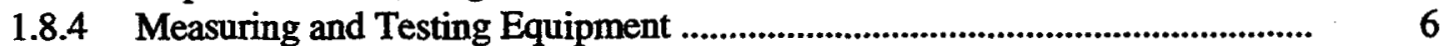

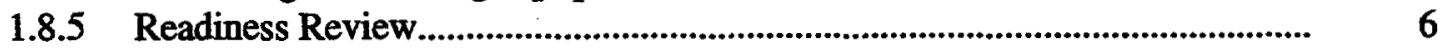

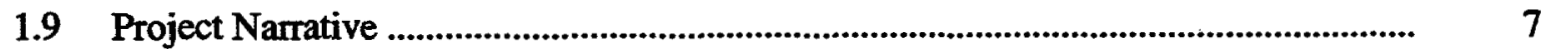

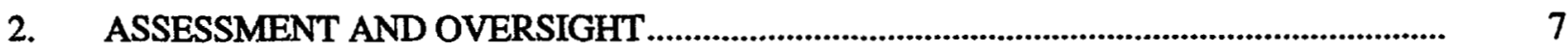

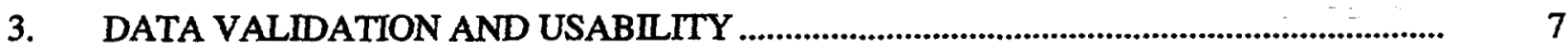

3.1 Data Review, Validation, and Verification Requirements..................................... 7

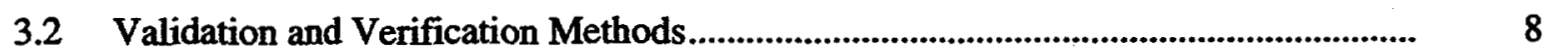

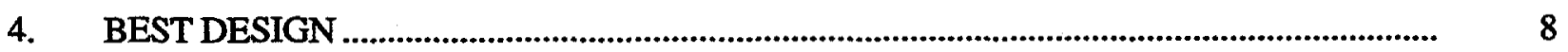

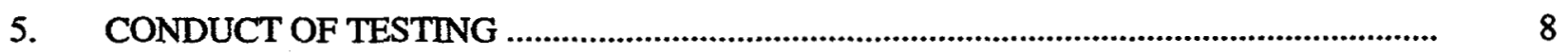




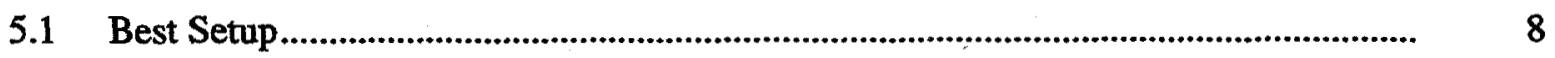

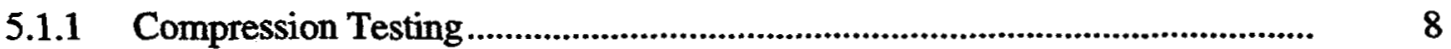

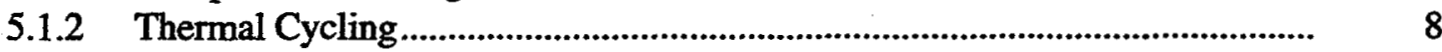

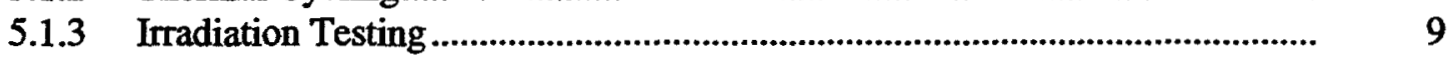

5.1.4 Biodegradation Testing ............................................................................. 9

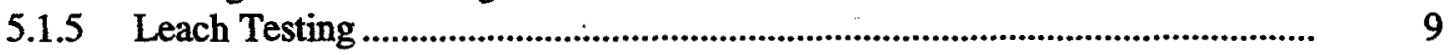

5.1.6 Immersion Testing............................................................................................ 10

5.1.7 Free Standing Liquid .................................................................................... 10

5.1 .8 Full Scale Testing.................................................................................... $\quad 10$

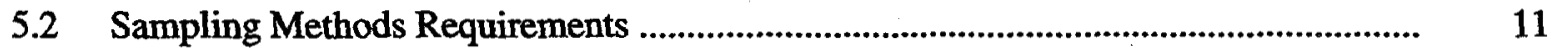

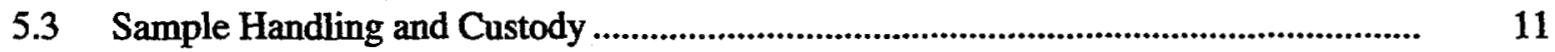

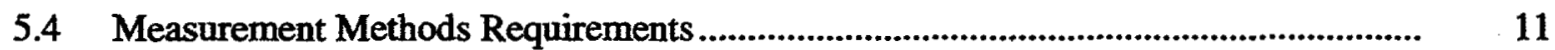

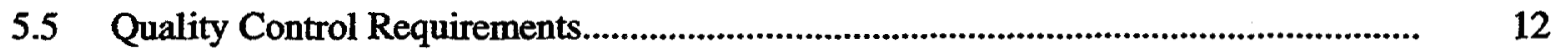

5.6 Instrument and Equipment Testing, Inspection and Maintenance Requirements ......... 12

Instrument and Equipment Calibration and Frequency .......................................... 12

5.8 Inspection/Acceptance Requirements for Supplies and Consumables ........................ $\quad 12$

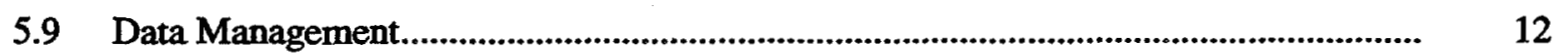

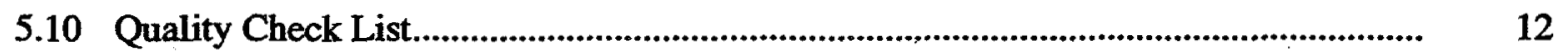

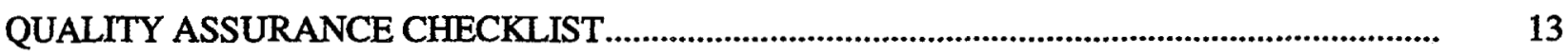

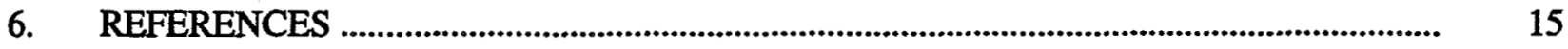




\title{
NRC Branch Technical Position Test Program Quality Assurance Program Plan
}

\author{
Revision 0
}

\section{PROGRAM MANAGEMENT}

This Quality Assurance Program Plan (QAPP) describes the quality assurance (QA) and quality control (QC) measures required to ensure the validity of the data acquired for the NRC Branch Technical Position Test Program from selected test methods used to assess the stability of waste forms that are expected to be disposed of as low-level waste. Inasmuch as a number of waste form types are expected to be tested, it is expected that tests to be performed on a specific waste form may change, depending on the type of waste formtested.

\subsection{Problem Definition and Background}

The Technical Position outlines the NRC's regulatory position. Low-level wastes are classified as Class A, B, or C, depending on their perceived disposal hazard. Class A wastes are considered the least hazardous and Class $C$ are the most hazardous. Certain minimum requirements must be met by all wastes, which are given in 10 CFR 61.56(a). ${ }^{2}$ They involve basic packaging requirements, prohibition against the disposal of pyrophoric, explosive, toxic, and infectious materials, and requirements to solidify or absorb liquids. ${ }^{1}$ Class $\mathrm{B}$ and $\mathrm{C}$ wastes have the additional requirement that they have "structural integrity" under expected disposal conditions. This will prevent the slumping or collapse of the disposal system and also prevent accelerated release of radionuclides caused by the disintegration of the waste form that would provide increase surface area for leaching.

\subsection{Program Organization}

The program organization is as follows:

Waste Operations - J. A. Vanvliet (Director)

National Low-Level Waste Program -

Project Manager -

Principal Investigator - D. W. Akers

\subsection{Program Description}

The specific requirements that must be met to demonstrate stability of Class $B$ and $C$ wastes is determined by assessing the following conditions stipulated by the Technical Position:

- The waste should be solid or in a container or structure that provides stability after disposal. (Such high-integrity containers are required by the NRC to have a design life of at least 300 years). 
- The wastes should not contain free-standing or corrosive liquids. That is, the wastes should contain only trace amounts of liquids. When the wastes are placed in a high-integrity container that provides stability, the free liquid must not exceed $1 \%$ by volume of the waste. For solidified wastes, the volume of free liquid must not exceed $0.5 \%$ of the waste volume.

- The waste or container should be resistant to degradation caused by radiation.

- The waste or container should be resistant to biodegradation.

- The waste or container should remain stable under the compressive loads in the disposal environment.

- The waste or container should remain stable if exposed to moisture or water after disposal.

- The as-generated waste should be compatible with the solidification medium or container.

To ensure that wastes streams are treated to produce uniform waste forms suitable for disposal, generators are required to process wastes streams according to a plant-specific process control procedure (PCP) that documents the treatment process for NRC review. The qualification tests that must be performed to judge whether a waste form meets the requirements are-

- Compression testing

- Thermal cycling

- Irradiation testing

- Biodegradation testing

- $\quad$ Leach testing

- Immersion testing

- Free-standing liquid testing

- Full-scale waste form testing.

\subsection{Program Documents}

The primary program documents associated with this project are the test plan and this QAPP. Laboratory analysis methods to be used are those approved as procedures from "qualified" laboratories as defined in the test plan and the quality requirements defined in this document. Split samples will be sent to qualified laboratories at the INEL and at offsite laboratories as confirmatory analysis of the results.

\subsubsection{Quality Assurance Program Plan}

This QAPP describes the activities to be undertaken in support of NRC Branch Technical Position Test Program. This QAPP also describes both management and technical aspects of the test program, 
including data quality objectives (DQO), data collection and reporting requirements, and QA/QC requirements to which the data collection activities must comply.

\subsubsection{Test Plan}

The test plan and procedures are summarized in Sections 4 and 5 of this document and in detail in the test plan (INEEL/EXT-97-01142) Rev. 0, October 1997. The basic test will subject new waste forms to a series of tests as defined in the NRC Branch Technical Position requirements for waste form testing.

Several tests are described in the test plan to assess the effects of different parameters on the stability of the waste form. Specific test protocols that may be performed are-

Test Protocol

- Compression testing

- Thermal cycling

- Irradiation testing

- Biodegradation testing

- $\quad$ Leach testing

- Immersion testing

- Free-standing liquid testing,

- Full-scale waste form testing $\underline{\text { Standard }}$

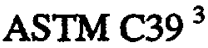

ASTM B-553 Section 5.4.1 through 5.4.4

BTP requirements ${ }^{3}$

ASTM G21 and G22 5,6

ANSI $16.1^{7}$

BTP requirements ${ }^{1}$

ANS $55.1^{8}$

BTP requirements ${ }^{1}$

\subsubsection{Document Review, Approval, and Control}

The final document review and approval will be performed by the program manager. Document control will be performed by the National Low-Level Waste Program. A final report will be generated at the conclusion of the experiments and will be reviewed by the DOE-ID project office prior to being released to the public.

\subsection{Data Quality Objectives for Measurement Data}

The DQOs are qualitative and quantitative statements that clarify the technical and quality objectives, define the appropriate type of data, and specify the tolerable levels of data variation that will be used as the basis for establishing the QA/QC.

The primary DQO is to perform the tests defined in the test plan using appropriate validated and calibrated test methods to assess the stability of the waste form being tested. 


\section{Specific DQOs}

1. Ensure all volumetric and weighing devices are calibrated within $5 \%$ of the stated accuracy and that current calibration data are present.

2. Determine values within an uncertainty of less than $20 \%$.

3. Ensure that all measuring systems are calibrated within $10 \%$ and that a current calibration is in place.

4. Ensure that all measurement system calibration data are appropriately obtained and are retained in EDFs for this project.

5. To ensure that data are accurate, perform duplicate analyses at an outside laboratory to verify results.

6. All reference materials used for system calibrations will be traceable to NIST and have uncertainties associated with the reference material that are less than $5 \%$.

7. Control samples will be submitted with each sample set to allow analytical quality to be assessed.

\subsection{Training Requirements}

Training will emphasize correct work performance, data quality, and safety requirements. Each person involved in this project will be selected by the principal investigator (PI) and be qualified to perform his or her part of the project based upon education and previous work experience. Safety training for laboratory personnel will include at a minimum-

- General Laboratory Safety Training

- Radiation Worker Training .

All training will be documented. The training records will kept and maintained by the department's training coordinator.

\subsection{Documentation and Records}

The following list of records will be controlled and maintained in support of this project:

- Work Package Documentation

- $\quad$ Engineering Design File

- Test Plan Documentation

- Laboratory Notebook (sec. 1.7.1) 
- Data sheet with sign offs (see test plan) and QA checklist (attached)

- Final Data Package (sec. 1.7.2).

\subsubsection{Laboratory Notebook}

A laboratory notebook will be kept as a permanent record of how the test was conducted. This notebook will serve as a log of all analytical work and will include the following items:

- Date and time of data entry

- Weights or liquid volume, with uncertainty values

- Recordable measurement data

- $\quad \mathrm{pH}$ and conductivity measurements for start and end of each sampling period

- Date and time of each sampling

- Radiochemistry results for liquids, filters, and gas trap samples

- Any personal observations of things that might bias the outcome of the experiment.

\subsubsection{Final Data Package}

A final data package will be prepared at the conclusion of the NRC Branch Technical Position Tests. This data package will contain the following information:

- A project narrative that describes the experiment and contains the results from the experiment

- A case narrative that reports any anomalies that occur and any deviation from required procedures and the reasons for the deviations

- A hard copy of the data analysis workup

- Quality control summary sheets will include comparison of control samples analysis with submitted samples

- Data review and validation checklist from the PI

- Data verification checklist from the quality assurance officer

- Hard copies of the raw data

- $\quad$ Any pertinent notes from the laboratory notebook. 


\subsection{Work Processes}

All work processes will be performed according to the procedural steps outlined in this document. Radiochemistry work will be performed according to the Radiological Measurement Laboratory's standard practices and/or at "qualified" external laboratories that meet the requirements of the LMITCO Sample Management Office. Any deviations will be noted in the Laboratory Notebook with explanation for the deviation.

\subsubsection{Control of Processes}

All work will be directed by a cognizant PI. The PI will oversee each aspect of the experiment and ensure that the procedures are followed and DQOs are met as outlined in this QAPP.

\subsubsection{Identification and Control of Items}

The PI or designated cognizant person will personally oversee all aspects of procurement for this project. He or she will ensure that the proper materials are received and meet the design criteria for their intended applications. No materials will be used that do not meet the design criteria. All reference materials will be traceable to the NIST and have a current expiration date that denotes the material's intended shelf life.

\subsubsection{Inspection and Testing}

Prior to the emplacement of actual samples into the fluidized bed apparatus, an inspection and testing phase will be completed to ensure proper operation and ruggedness for its intended application. No radioactive materials will be placed into these systems if any faults are observed during the testing phase of this experiment.

\subsubsection{Measuring and Testing Equipment}

All measurement and testing equipment will be calibrated by the user (operator) before performing sample measurements or have a current calibration as performed by the INEEL Calibrations Laboratory. All required calibrations will be identified in the sign-off sheet with the required degree of certainty. All reference materials used to calibrate analytical instrumentation will have a certification that includes the uncertainty and the materials expiration date. All volumetric glassware will be Class A certified from the manufacture and conform to the ASTM specifications E617-78 and E694-79.

\subsubsection{Readiness Review}

Prior to beginning the experiments, a readiness review will be conducted and overseen by the program manager or designated alternate. Initial preparatory requirements for beginning the measurements are listed in the test plan. The PI and laboratory staff will be in attendance or have prepared comments or concerns (if any) submitted to the PI to be addressed during the readiness review. 


\subsection{Project Narrative}

This project will be to perform the BTP tests such that the results can be validated and verified from initial calibration data and the use of duplicate samples during the testing process to ensure that the accuracy and precision guidelines defined in this document are met.

\section{ASSESSMENT AND OVERSIGHT}

Periodic oversight will be conducted by the Program Manager through the PI to ensure that the experiments are being conducted according to the test plan outlined in Sections 4 and 5. Data review will be conducted by the PI to ensure that the tests being performed are being done correctly, with adequately calibrated equipment and appropriate recording of the data, to ensure an accurate assessment of the stability of the waste forms.

Periodic experiment inspections will be conducted by the cognizant PI to ensure that the testing apparatus is functioning according to the design criteria, i.e., proper bed fluidization with an acceptable flow rate, without clogging or channeling of the soil bed.

\section{DATA VALIDATION AND USABILITY}

Data generated for the NRC Branch Technical Position Test Program must be reviewed, validated, and verified prior to use. Data review determines if data have been properly collected and ensures that data are properly reduced. Data validation confirms that the data reported satisfy the requirements defined by the data user. Data verification authenticates that data are, in fact, those which are claimed. The procedures included in this section ensure that PA data records furnish documentary evidence of quality.

\subsection{Data Review, Validation, and Verification Requirements}

Experimental data review and work up will be performed by the PI or designated alternate. Final data review and validation will be performed by the PI. Verification of the data quality will be performed by an independent quality assurance officer.

A Q/A check list will be completed by the quality assurance officer to document the steps taken in the data validation and verification. This check list will be included with the final data package.

Specific validation requirements are as follows:

1. At least two duplicate samples will be sent with each group of samples being sent to any laboratory that is being used for analysis.

2. A spiked control sample will be sent with each sample batch to ensure accuracy of the measurement data.

3. All laboratory quality assurance data will be provided for review by the principal investigator and the quality officer. 


\subsection{Validation and Verification Methods}

The QA checklist is based on EPA's "Report on Minimum Criteria to Assure Data Quality" but modified to more accurately reflect the radiochemical analysis procedures and techniques. This checklist is incorporated in Appendix A of this document.

\section{TEST DESIGN}

The test design requirements are specified in the procedures present in Appendix A of the Test Plan for this project. Any changes in procedure necessitated by waste form characteristics will be specified in the test report on the waste form, and the effects on the results of the test will be evaluated. Specific test equipment will be described in the report of the results of the tests.

\section{CONDUCT OF TESTING}

This section outlines the general methodology for conducting the NRC Branch Technical Position Test Program for the tests to be performed.

\subsection{Test Setup}

\subsubsection{Compression Testing}

Waste forms must have a sufficiently high compressive strength to avoid disintegration from burial stresses and to prevent burial facility slumping. The Technical Position requires a compressive strength of at least 60 pounds per square inch (psi). However, the NRC recommends that generators achieve "maximum practical compressive strength," rather than just the minimum. For cement-based waste forms, the NRC specifies a minimum acceptable compressive strength of 500 psi. This is readily achievable in most cases since the typical compressive strength of a cementitious waste form is about 5000 psi.

Measurements on nonradioactive samples will be performed using compression test systems at the Idaho Research Center. Appropriate calibration data will be obtained and new calibrations performed to ensure that the system is adequately calibrated to meet the ASTM requirements.

\subsubsection{Thermal Cycling}

The thermal cycling procedure will be that given in ASTM B-553, ${ }^{4}$ Section 5.4.1 through 5.4.4. To be acceptable, "bare" waste forms (no containers) must undergo 30 thermal cycles between $60^{\circ} \mathrm{C}$ and $-40^{\circ} \mathrm{C}$, and a subsequent compression strength test (ASTM C39) must demonstrate that the compressive strength is at least 60 psi. For cementitious waste forms, the strength must be at least 500 psi.

Thermal cycling will be done with an existing programmable furnace system that can be used for programmed cycling functions. Tests will be performed to assess the rate of temperature change and the accuracy of the furnace temperature measurement system. Compression measurements on nonradioactive samples will be performed using compression test systems at the Idaho Research Center. Appropriate calibration data will be obtained and new calibrations performed to ensure that the system is adequately calibrated to meet the ASTM requirements. 


\subsubsection{Irradiation Testing}

Waste forms must be gamma irradiated at ambient temperature to at least $10^{8} \mathrm{rad}$, or to a higher maximum value if that is expected for a particular waste form. After irradiation, the waste forms are tested for compressive strength. The strength must be at least $60 \mathrm{psi}$, or at least 500 psi for cementitious waste forms.

The waste forms will measure 2 in. in diameter by 4 in. in length. After irradiation, the samples will be compression tested and the average strength and the standard deviation determined. Values will be compared to those for nonirradiated controls.

Total irradiation will be determined using dosimeter materials where the total irradiation can be determined by gamma spectrometry analysis. The total irradiation must exceed the specified requirements, or the characteristics of the waste form must be such that irradiation effects are not feasible. Compressions testing will be performed at the Idaho Research Center.

\subsubsection{Biodegradation Testing}

The ASTM Standards G21 (fungal) and G22 (bacterial) are recommended by the NRC for the purpose of biodegradation testing. No sign of biodegradation should be observable, and the compressive strength after biodegradation testing should be at least $60 \mathrm{psi}$, or 500 psi for cementitious waste forms.

In the ASTM G21 test, a suspension of the fungal inoculant will be sprayed onto the agar and the sample surfaces, which will be maintained at $28-30^{\circ} \mathrm{C}$, at $85 \%$ relative humidity, for 21 days. They will be checked periodically for fungal growth.

In the G22 tests, samples are placed on the nutrient-salt agar and sprayed with the bacterium pseudomonas aeruginosa. The samples will be maintained at $35-37^{\circ} \mathrm{C}$, at $85 \%$ relative humidity, for 21 days. Periodically, they will be examined for bacterial growth. After the G21 and G22 tests, the specimens will be tested to determine whether they meet the compressive strength requirements described above.

Bacterial and fungal testing will be performed at the Idaho Research Center per the specifications identified in the ASTM standards. Appropriate calibration of the temperature and humidity measuring devices will be performed. Compression testing will be performed at the IRC.

\subsubsection{Leach Testing}

Leach testing of waste forms is undertaken to demonstrate that releases off-site due to contact with groundwater are within prescribed limits. The limit is given as a Leachability Index $(\mathrm{L})$, which is the arithmetic mean of the $L$ values obtained for each leaching interval. $L$ is the logarithm of the effective diffusivity of each radionuclide of interest. A waste form has an acceptable leachability if $L$ is greater than 6.

The ANSUANS 16.1 standard will serve as the leaching procedure used. Leaching will be performed for a period of 90 days, except for cementitious samples, which will be leach tested for 5 days. Deionized water or synthetic seawater will be considered for the leachant, depending on which is shown from preliminary testing to give the highest leach rate. This will ensure that conservative leachability indices are measured. 
Measurements of $\mathrm{pH}$, conductivity, and water temperature will be performed to ensure that the requirements for leaching characteristics are met. In addition, a standard composition for seawater will be used and the composition verified by evaluation of logbooks that describe the fabrication process.

\subsubsection{Immersion Testing}

Immersion testing in either deionized water or synthetic seawater will be conducted to determine if a waste form maintains its structural integrity after burial. Short-term tests are initially carried out to determine the most aggressive immersion medium before one or the other is selected for the 90-day immersion tests. Specimens will be cured for 28 days before testing commences.

During the immersion period, they will be visually inspected for evidence of cracking, spalling, or disintegration. If there is no significant immersion effects, the waste forms will be compression tested, as described above. The waste forms should have a compressive strength of at least $60 \mathrm{psi}$, except for cementitious waste forms which must have a strength of at least 500 psi, but not less than $75 \%$ of the preimmersion value. If the average postimmersion compressive strength for cementitious samples is less than $75 \%$ of the preimmersion value, additional samples from the same batch will be immersion tested for an extended period of 180 days total to ensure that the long-term strength does not continue to decline with time.

For certain types of waste streams (viz., bead resins, chelates, filter sludges, and floor drain wastes) additional immersion tests will be carried out. Such specimens will be cured for 180 days in sealed containers. The immersion period will be for 7 days, followed by drying in ambient air at a minimum temperature of $20^{\circ} \mathrm{C}$ for another 7 days. After drying, the samples will be visually inspected for cracking or spalling and then compression tested as described above. The average compressive strength and the standard deviation will be determined.

\subsubsection{Free Standing Liquid}

Excessive amounts of free standing liquids in contact with waste forms and their containers must be avoided to minimize the release of contaminants and container corrosion. The amount of liquid must not exceed $1 \%$ of the waste volume if the waste is placed in a high-integrity container, or less than $0.5 \%$ of the waste volume for other containers. The $\mathrm{pH}$ of the liquid must be between 4 and 11, except for cementitious waste forms, for which the liquid $\mathrm{pH}$ must be at least 9 .

Appropriate calibration of $\mathrm{pH}$ meters will be performed and documented along with the liquid measurement devices used to measure any free standing water that may be present.

\subsubsection{Full Scale Testing}

To ensure that laboratory-scale tests reflect the behavior of full-scale forms, actual prototype waste forms will be prepared. Triplicate samples ( 2 in. in dia. $\times 2$ in. in length) will be removed from selected locations of each waste form by sectioning or coring. Assuming that the waste forms are of 55-gallon drum size, the samples will be taken from the center and other regions of the cylindrical forms at locations $1 / 3$ and $2 / 3$ from the bottom of the forms. This will give four testing locations, with 3 samples per location for each waste form. 
The following tests will be performed to check the integrity of the full-scale waste forms:

1. Perform compression tests on the batches of samples after they have been cured for at least 28 days, to determine whether they are similar to those for the laboratory-scale samples

2. Perform 90-day immersion tests followed by compression testing, to determine that the full-scale waste form gives similar results to the laboratory-scale samples

3. Check the samples destructively and compare them to determine whether there is homogeneity within the original full-scale waste form.

All compression tests will be performed at the INEEL laboratories along with other measurements used to assess the characteristics of the cored waste forms.

\subsection{Sampling Methods Requirements}

Sampling will be performed on samples to be measured that have been agitated and on solid samples that have been mixed to ensure representative samples. Sample sizes will be sufficiently large to ensure that inhomogeneities are not present.

\subsection{Sample Handling and Custody}

All samples will be labeled with the following information:

- Date

- $\quad$ Time

- A unique sample description

- Sampler's initials.

All samples and analysis data will be kept in a logbook with operator signoffs. A procedural page will be generated for each sample, which requires that all analyses specified for each sample type will be addressed and signed off (see test plan). Because all of the sampling, sample handling, and instrumental measurements will be performed within the same group, no other formal chain of custody documentation will be required.

\subsection{Measurement Methods Requirements}

The specific methods used to perform these measurements have been established, tested, and verified by the Sample Management Office. Gamma spectral analysis will be performed for the leaching radionuclides by the INEEL Radiation Measurements Laboratory (RML). This measurement data, along with appropriate calibration data, will be retained in an appropriate engineering design file. All applicable procedures for the analyses will be followed. Any deviations must be included in a case narrative in which the sample analysis and measurement data are submitted for incorporation in the analysis report. 


\subsection{Quality Control Requirements}

Basic quality assurance for the sample analysis work will be determined through regular checks with NIST standards for the gamma spectrometer systems and traceability to NIST standards for other measurements.

Sufficient archival material will be retained to ensure that re-analysis of all samples is possible. In addition, a mass balance for each sample analysis series will be determined. A review of all data and analytical results will be performed, and if the discrepancy is not resolved, reanalysis or retesting of specific samples will be performed to provide assurance that the sample analysis results meet the data quality objectives.

\subsection{Instrument and Equipment Testing, Inspection and Maintenance Requirements}

Instrument testing will be performed per the laboratory-designated requirements and identified in the instrument log.

\subsection{Instrument and Equipment Calibration and Frequency}

The instrument and equipment calibration frequency will be specified in the laboratory operating procedures. Quality assurance checks will be performed per the laboratory requirement. Known samples will be analyzed to ensure quality assurance.

\subsection{Inspection/Acceptance Requirements for Supplies and Consumables}

Consumables including radioactive tracers will be tested using a secondary test method to ensure that these items meet the certification and NIST-stated concentrations.

\subsection{Data Management}

Laboratory and analytical results sheets will be appended to EDFs documenting the test. Results and analytical calculation methods will be described in EDFs that describe the process. All process calculations will be reproducible and checkable from the EDF. Additionally, quality assurance reviews will be performed through duplicate sample analyses.

\subsection{Quality Check List}

The quality assurance checklist is presented on the next page. 


\section{QUALITY ASSURANCE CHECKLIST}

- Quality Assurance Program Plan approved

- Test Plan approved

- Test procedure approved

- Lab personnel safety training current

- Independent safety review committee approval

- Radiological safety analysis completed

- Radiological analysis procedures in place and current

- Readiness review conducted

- Review comments evaluated and incorporated in test procedure

\begin{tabular}{|l|l|}
\hline & \\
\hline & \\
\hline & \\
\hline & \\
\hline & \\
\hline & \\
\hline & \\
\hline & $\cdots$ \\
\hline & \\
\hline
\end{tabular}

\section{Instrument Calibrations}

- $\quad \mathrm{pH}$ meter standardization-buffer solutions $7 \& 10$ standardize daily-accuracy $\forall 0.05 \mathrm{pH}$ unit.

- Conductivity meter- $0.010 \mathrm{Molar} \mathrm{KCl}$ solution $1413 \Phi \mathrm{mho} / \mathrm{cm} \forall 50 \Phi \mathrm{mho} / \mathrm{cm}$-check weekly.

- Gamma spectrometer calibrations current as per standard operating procedures

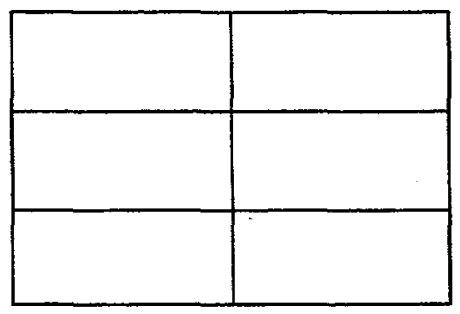

\section{Standardization \& Reference Material}

- Surrogate ground water chemicals ACS reagent grade or better

- $\quad$ pH buffer solutions expiration dates current

- Radiological tracer spiking solutions NIST traceable

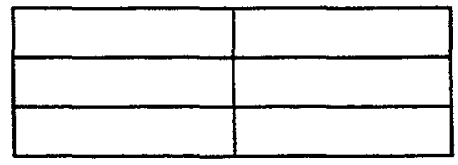

\section{Data Review and Validation}

- Laboratory notebook reviewed for project required information

- Laboratory notebook signed off by lab personnel

- Radio tracers decay corrected for short-lived isotopes

- Data validated by principal investigator

- Data calculations verified

- Quality control samples within control limits as specified in analytical procedures

- Case narrative written

- Data package complete

\begin{tabular}{|l|l|}
\hline & \\
\hline & \\
\hline & \\
\hline & \\
\hline & \\
\hline & \\
\hline & \\
\hline & \\
\hline
\end{tabular}




\section{REFERENCES}

1. ATechnical Position on Waste Form (Revision 1),ฏ NRC, January 1991.

2. ALicensing Requirements for land Disposal of Radioactive Waste, $\cong$ Code of Federal Regulations 10 CFR Part 61.

3. American Society for Testing and Materials Standard Test Method for Compressive Strength of Cylindrical Concrete Specimens, ASTM C39, October 1984.

4. American Society for Testing and Materials Standard Test for the Thermal Cycling of Electroplated Plastics, ASTM B553, 1979.

5. American Society for Testing and Materials Standard Test for Determining Resistance of Synthetic Polymneric Materials to Fungi, ASTM G21, 1970.

6. American Society for Testing and Materials Standard Test for Determining Resistance of Plastics to Bacteria, ASTM G22, 1976.

7. AMeasurement of the Leachability of Solidified Low-level Radioactive Wastes by a Short-term Test Procedure, $\cong$ ANSI/ANS Standard 16.1, American National Standards Institute/American Nuclear Society, 1988.

8. ASolid Radioactive Waste Processing System for Light Water Cooled Reactor Plants, Appendix 2," ANSU/ANS standard 55.1, American National Standards. 
Appendix F

Draft Test Plan 


\title{
NRC Branch Technical Position Test Program Test Plan
}

Revision 0 (Draft)

\author{
D. W. Akers
}

Published October 1997

Idaho National Engineering and Environmental Laboratory

Lockheed Martin Idaho Technologies Company Idaho Falls, Idaho 83415

Prepared for the

U.S. Department of Energy

Assistant Secretary for Environmental Management

Under DOE Idaho Operations Office

Contract DE-AC07-941D13223 


\section{NRC Branch Technical Position Test Program Test Plan}

Revision 0

Approved by:

Program Manager

Date:

Approved by:

Principle Investigator

Date:

Approved by:

RWMC QA Officer

Date:

Reviewed by:

Date:

Reviewed by:

Date:

Reviewed by:

Date:

Reviewed by:

Date:

Prepared by:

Date: 


\begin{abstract}
This test plan describes the objectives, scope, participants, and methods to be used for the NRC Branch Technical Position Test Program. This work is being performed in support of the National Low-Level Waste Management Program to provide the capability for performing qualification of waste forms to be used for low-level waste disposal. This plan details the experimental design and test conditions for the assessment of the waste forms using the ANSI/ANS 16.1 test series. Quality assurance requirements for this test plan are described in the Quality Assurance Program Plan for the NRC Branch Technical Position Test Program.
\end{abstract}




\section{CONTENTS}

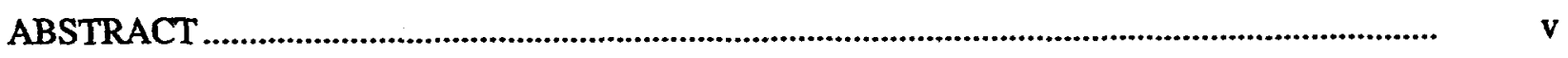

1. INTRODUCTION …….....................................................................................................

1.1 Background.......................................................................................................

1.2 Objectives..........................................................................................................

1.3 Technical Basis ......................................................................................................

1.4 Activities ............................................................................................................

2. PROGRAM PARTICIPANTS AND RESPONSIBILITIES …….............................................

3. PROGRAM DOCUMENTS ................................................................................................

3.1 Quality Assurance Program Plan ..................................................................................

4. TEST METHOD ……..........................................................................................................

4.1 Compression Testing.................................................................................................. 4

4.1.1 Acceptance criteria ............................................................................................

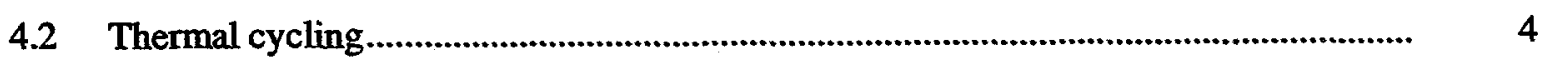

4.2.1 Acceptance criteria ....................................................................................

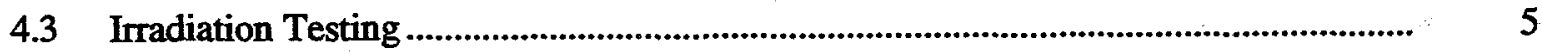

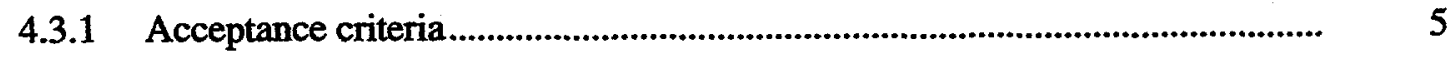

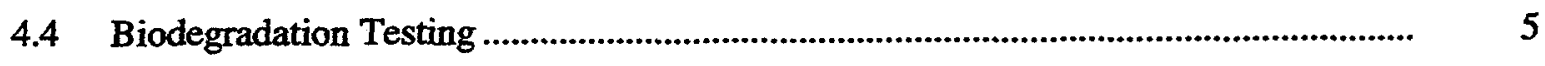

4.4.1 Acceptance Criteria .................................................................................... 5

$4.5 \quad$ Leach Testing ...................................................................................................... 5

4.5.1 Acceptance Criteria ................................................................................... 6

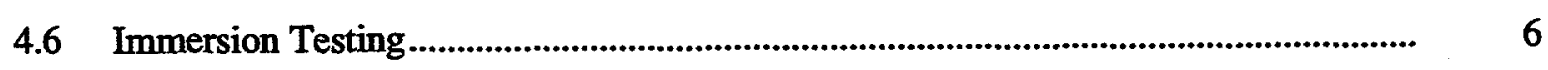

4.6.1 Acceptance Criteria ...................................................................................... 6

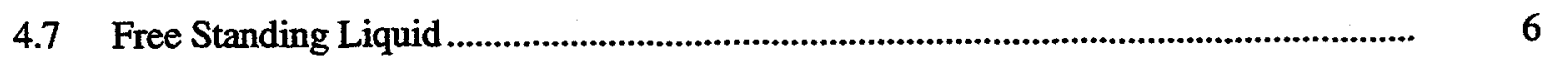

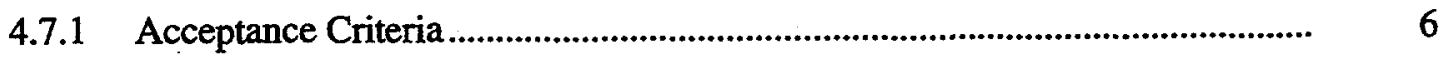


$4.8 \quad$ Full Scale Testing ...................................................................................................

4.9 Conduct of NRC Branch Technical Position Tests..................................................... 7

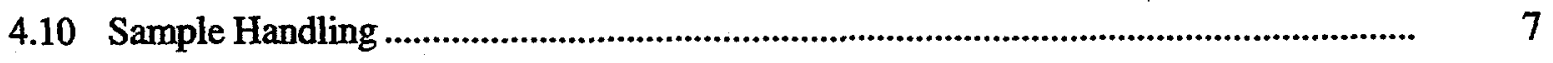

5. DATA MANAGEMENT AND ANALYSIS ……………………...................................... 7

$5.1 \quad$ Validation of Data .....................................................................................................

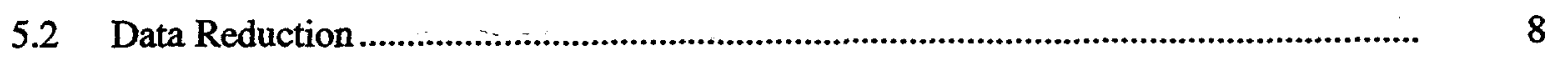

6. DATA REPORTING ………....................................................................................... 8

7. REFERENCES ……...................................................................................................... 8 


\section{NRC Branch Technical Position Test Program Test Plan}

\section{INTRODUCTION}

The NRC Branch Technical Position Test Program Test Plan describes the experimental design and test parameters to be employed to assess the stability of waste forms that are proposed for use in the disposal of low-level wastes at commercial burial sites. These tests provide the initial qualification of the waste form prior to actual waste form testing to be performed on wastes from commercial facilities being solidified for disposal. This test plan also presents the technical basis for the experimental design and data quality objectives and describes the equipment and basic procedures to be used to perform the experiments.

\subsection{Background}

The NRC's "Technical Position on Waste form, Revision 1," dated January 1991, ${ }^{1}$ requires that buried waste forms preserve their structural integrity and be capable of resisting degradation that could cause excessive releases of radioactive constituents to the environment. A series of tests has been specified by the NRC in the Technical Position that quantify the behavior of waste forms under simulated burial conditions. Generators who provide these test data and show that their waste formulations meet regulatory requirements may receive NRC approval for their waste formulations.

The Technical Position outlines the NRC's regulatory position. Low-level wastes are classified as Class A, B, or C, depending on their perceived disposal hazard. Class A wastes are considered the least hazardous and Class $\mathrm{C}$ are the most hazardous. Certain minimum requirements must be met by all wastes given in 10 CFR 61.56(a). ${ }^{2}$ They involve basic packaging requirements, prohibition against the disposal of pyrophoric, explosive, toxic and infectious materials, and requirements to solidify or absorb liquids ${ }^{(1)}$. Class B and C wastes have the additional requirement that they have "structural integrity" under expected disposal conditions. This will prevent the slumping or collapse of the disposal system, and also prevent accelerated release of radionuclides caused by the disintegration of the waste form, which would increase the surface area for leaching.

To ensure that waste streams are treated to produce uniform waste forms suitable for disposal, generators are required to process wastes streams according to a plant-specific process control procedure (PCP) that documents the treatment process for NRC review. The qualification tests that must be performed to judge whether a waste form meets the requirements are-

- Compression testing

- Thermal cycling

- Irradiation testing

- Biodegradation testing

- Leach testing 
- Immersion testing

- $\quad$ Free-standing liquid testing

- Full-scale waste form testing.

To minimize costs, attempts will be made to use simulated, nonradioactive waste streams in this work. For leach testing, however, representative radioactive tracers will be used to dope the specimens, since leachants can be accurately tested for radionuclide content using standard counting procedures.

\subsection{Objectives}

The purpose of this test plan is to outline the background, methods, sampling techniques, control measures, safety, and quality requirements needed to perform the series of tests listed in Section 1.1. The specific tests have a range of initial testing, calibration, and verification measurements that must be performed to provide assurance that NRC Branch Technical position requirements are met.

\subsection{Technical Basis}

The NRC technical position on waste form was initially developed in 1983 to provide guidance to both fuel-cycle and nonfuel-cycle waste generators on waste form test methods and results acceptable to the NRC staff for implementation of the 10 CFR 61 requirements and meeting the waste stability requirements in this regulation. The specific requirements that must be met to demonstrate stability of Class $\mathrm{B}$ and $\mathrm{C}$ wastes is determined by assessing the following conditions stipulated by the Technical Position:

- The waste should be solid or in a container or structure that provides stability after disposal. (Such high-integrity containers are required by the NRC to have a design life of at least 300 years).

- The wastes should not contain free-standing or corrosive liquids. That is, the wastes should contain only trace amounts of liquids. When the wastes are placed in a high-integrity container that provides stability, the free liquid must not exceed $1 \%$ by volume of the waste. For solidified wastes, the volume of free liquid must not exceed $0.5 \%$ of the waste volume.

- The waste or container should be resistant to degradation caused by radiation.

- The waste or container should be resistant to biodegradation.

- The waste or container should remain stable under the compressive loads in the disposal environment.

- The waste or container should remain stable if exposed to moisture or water after disposal.

- The as-generated waste should be compatible with the solidification medium or container. 


\subsection{Activities}

Activities planned for the NRC Branch Technical Position Test Program are as follows:

- Develop test matrix for the specific waste form being tested

- Ensure appropriate calibration data are available prior to beginning work for each of the measurements to be performed

- Perform initial waste characterization using TCLP test to ensure that waste disposal can be performed

- Design and construction of a recirculating flow system (fluidized bed apparatus) and batch test apparatus

- Performance of the initial test series

- Validation of the of the data where the results are inconclusive

- Data analysis and quality assurance review

- Prepare final data package.

\section{PROGRAM PARTICIPANTS AND RESPONSIBILITIES}

The participants in the NRC Branch Technical Position Tests are-

1. To be determined-Manager

D. W. Akers-Principal investigator

\section{PROGRAM DOCUMENTS}

The primary program documents associated with this project are this test plan and the quality assurance program plan noted below. Laboratory analysis methods to be used are those approved as procedures as part of the development of this test program including, calibration and measurements data. Split samples will be sent to qualified laboratories at the INEL and at offsite laboratories as confirmatory analysis of the results.

\subsection{Quality Assurance Program Plan}

The quality assurance requirements for this project are defined in the quality assurance program plan for this program. Quality assurance requirements for this test plan are described in the NRC Branch Technical Position Test Program Quality Assurance Program Plan. 


\section{TEST METHOD}

This section describes the experimental methodology to be used for the NRC Branch Technical Position Tests and includes the measurement requirements and validation data for the measurements.

\subsection{Compression Testing}

The compression testing procedure is that given in ASTM Standard C39. (In the case of bituminous waste forms, the testing methodology will be that described in ASTM Standard D1074. ${ }^{5}$ The standard test specimens will be right circular cylinders with a diameter of 2 in. and a length of 4 in. Prior to testing, the ends of the cylinders will be "capped" with a suitable nonreacting compound that will provide the parallel end surfaces needed for successful testing. A total of 5 replicate specimens will be tested and the average values of compressive strength and the standard deviation calculated.

\subsubsection{Acceptance criteria}

Waste forms must have a sufficiently high compressive strength to avoid disintegration from burial stresses and to prevent burial facility slumping. The Technical Position requires a compressive strength of at least $60 \mathrm{lb} / \mathrm{in}^{2}$ (psi). However, the NRC recommends that generators achieve "maximum practical compressive strength," rather than just the minimum. For cement-based waste forms, the NRC specifies a minimum acceptable compressive strength of $500 \mathrm{psi}$. This is readily achievable in most cases since the typical compressive strength of a cementitious waste form is about 5000 psi. $^{3}$

\subsection{Thermal Cycling}

The thermal cycling procedure will be that given in ASTM B-553, ${ }^{6}$ Section 5.4.1 through 5.4.4. Five replicate specimens will be tested and any spallation or cracking of the waste forms will be documented. The average compressive strength will be determined together with the standard deviation. At least one sample per batch will be checked with a thermocouple to ensure that the temperatures throughout the samples have reached equilibrium before the hold period commences for the two cycling temperatures.

\subsubsection{Acceptance Criteria}

Thermal cycling of waste forms will only occur during storage or transportation. Once the waste form is buried, the surrounding temperature will remain essentially constant. However, the NRC believes that thermal cycling should be used as a means of identifying those waste forms that have superior mechanical behavior. This is based on the fact that many waste forms contain a variety of constituents that have different thermal expansion rates. Since thermal cycling imposes internal mechanical stresses, it is assumed that any waste form that resists cracking or spalling during this test possesses superior mechanical integrity.

To be acceptable, "bare" waste forms (no containers) must undergo 30 thermal cycles between $60^{\circ} \mathrm{C}$ and $-40^{\circ} \mathrm{C}$, and a subsequent compression strength test (ASTM C39) must demonstrate that the compressive strength is at least $60 \mathrm{psi}$. For cementitious waste forms, the strength must be at least 500 psi. 


\subsection{Irradiation Testing}

The waste forms will measure 2 in. in diameter by 4 in. in length. Four specimens will be irradiated in air in the INEEL ATR Gamma Irradiation system to a dose of $10^{8} \mathrm{rad}$, at a dose rate of about $10^{6} \mathrm{rad} / \mathrm{h}$, at a GIF ambient temperature of $10^{\circ} \mathrm{C}$. Slight gamma heating will occur $\left(10-15^{\circ} \mathrm{C}\right)$, but it will have little effect on the irradiation damage process. After irradiation, the samples will be compression tested and the average strength and the standard deviation determined. Values will be compared to those for nonirradiated controls.

\subsubsection{Acceptance criteria}

Gamma radiation is often present in radioactive wastes. It causes ionization type damage that may cause gas generation and, also, strength and ductility changes in waste forms. Waste forms must be gamma-irradiated at ambient temperature to at least $10^{8} \mathrm{rad}$, or to a higher maximum value if that is expected for a particular waste form. After irradiation, the waste forms are tested for compressive strength. The strength must be at least $60 \mathrm{psi}$, or at least $500 \mathrm{psi}$ for cementitious waste forms.

\subsection{Biodegradation Testing}

In the ASTM G21 test, waste forms measuring 2 in. in diameter and 4 in. long will be exposed to a mixture of 5 different types of fungi. Five tests specimens will be placed in contact with a nutrient-salts agar mixture contained in a sterile dish. A suspension of the fungal inoculant will be sprayed onto the agar and the sample surfaces, which will be maintained at $28-30^{\circ} \mathrm{C}$, at $85 \%$ relative humidity, for 21 days. They will be checked periodically for fungal growth.

In the G22 tests, 5 samples will be placed on the nutrient-salt agar and sprayed with the bacterium Pseudomonas aeruginosa. The samples will be maintained at $35-37^{\circ} \mathrm{C}$, at $85 \%$ relative humidity, for 21 days. Periodically, they will be examined for bacterial growth.

After the G21 and G22 tests, the specimens will be tested to determine whether they meet the compressive strength requirements described above.

\subsubsection{Acceptance Criteria}

Waste forms must be tested for biodegradation (fungal and bacterial) to determine the importance of these types of degradation. The ASTM Standards G21 (fungal) ${ }^{7}$ and G22 (bacterial). ${ }^{8}$ are recommended by the NRC for this purpose. No sign of biodegradation should be observable, and the compressive strength after biodegradation testing should be at least $60 \mathrm{psi}$, or 500 psi for cementitious waste forms.

\subsection{Leach Testing}

The ANSI/ANS 16.1 standard will serve as the leaching procedure to be used. ${ }^{9}$ Three specimens per batch will be tested. They will measure 2 in. in diameter by 4 in. in length. Leaching will be performed for a period of 90 days, except for cementitious samples, which will be leach tested for 5 days. Deionized water or synthetic seawater will be considered for the leachant, depending on which is shown from preliminary testing to give the highest leach rate. This will ensure that conservative leachability indices are measured. 


\subsubsection{Acceptance Criteria}

Leach testing of waste forms is undertaken to demonstrate that releases off-site due to contact with groundwater are within prescribed limits. The limit is given as a leachability index $(L)$, which is the arithmetic mean of the $L$ values obtained for each leaching interval. $L$ is the logarithm of the effective diffusivity of each radionuclide of interest. A waste form has an acceptable leachability if $L$ is greater than 6.

\subsection{Immersion Testing}

Five specimens per batch will be tested. During the immersion period, they will be visually inspected for evidence of cracking, spalling, or disintegration. If there is no significant immersion effects, the waste forms will be compression tested, as described above. The waste forms should have a compressive strength of at least $60 \mathrm{psi}$, except for cementitious waste form which must have a strength of at least 500 psi but not less than $75 \%$ of the pre-immersion value. If the average postimmersion compressive strength for cementitious samples is less than $75 \%$ of the preimmersion value, additional samples from the same batch will be immersion tested for an extended period of 180 days total to ensure that the long-term strength does not continue to decline with time.

For certain types of waste stream (viz., bead resins, chelates, filter sludges, and floor drain wastes) additional immersion tests will be carried out because they have been shown to exhibit complex behavior. ${ }^{10}$ Such specimens will be cured for 180 days in sealed containers. The immersion period will be for 7 days, followed by drying in ambient air at a minimum temperature of $20^{\circ} \mathrm{C}$ for another 7 days. After drying, the samples will be visually inspected for cracking or spalling and then compression tested, as described above. The average compressive strength and the standard deviation will be determined.

\subsubsection{Acceptance Criteria}

Immersion testing in either deionized water or synthetic seawater will be carried out to determine if a waste form maintains its structural integrity after burial. Short term tests will be initially carried out to determine the most aggressive immersion medium before one or the other is selected for the 90 day immersion tests. Specimens will be cured for 28 days before testing commences.

\subsection{Free Standing Liquid}

The ANS 55.1 methodology ${ }^{11}$ will be used to measure the amount of free-standing liquid. A suitable $\mathrm{pH}$ probe will be used to measure the $\mathrm{pH}$ of any free liquid.

\subsubsection{Acceptance Criteria}

Excessive amounts of free standing liquids in contact with waste forms and their containers must be avoided to minimize the release of contaminants and container corrosion. The amount of liquid must not exceed $1 \%$ of the waste volume if the waste is placed in a high-integrity container, or less than $0.5 \%$ of the waste volume for other containers. The $\mathrm{pH}$ of the liquid must be between 4 and 11, except for cementitious waste forms, for which the liquid $\mathrm{pH}$ must be at least 9 . 


\subsection{Full Scale Testing}

To ensure that laboratory scale-tests reflect the behavior of full-scale forms, actual prototype waste forms will be prepared. For each type of waste stream, two full-scale waste forms will be prepared by the vendor using procedures and equipment typical of that to be used in the field. Triplicate samples ( 2 in. in dia. $\times 2$ in. in length) will be removed from selected locations of each waste form by sectioning or coring. Assuming that the waste forms are of 55-gallon drum size, the samples will be taken from the center and other regions of the cylindrical forms at locations $1 / 3$ and $2 / 3$ from the bottom of the forms. This will give four testing locations, with 3 samples per location for each waste form.

The following tests will be performed to check the integrity of the full-scale waste forms:

1. Perform compression tests on the batches of samples after they have been cured for at least 28 days, to determine whether they are similar to those for the laboratory-scale samples

2. Perform 90-day immersion tests followed by compression testing, to determine that the full-scale waste form gives similar results to the laboratory-scale samples

3. Check the samples destructively and compare them to determine whether there is homogeneity within the original full-scale waste form.

\subsection{Conduct of NRC Branch Technical Position Tests}

This section addresses the procedures for conducting the NRC Branch Technical Position Tests. Specific procedures will be developed during the initial calibration period that meet the requirements of the tests identified in the previous sections. These procedures will be described in Appendix A, which will be added to this document.

\subsection{Sample Handling}

All sample materials will be photographed and a log kept of the materials, their location, and the processes performed on each sample.

\section{DATA MANAGEMENT AND ANALYSIS}

Data management and analysis involves several aspects. First, the data obtained in each portion of the test program must be validated to ensure that the quality assurance requirements have been met and that the data are suitable for use in waste disposal decisions. Second, all of the data for each experiment (where possible) must be summed to determine (within measurement error) that a mass balance has been attained. A mass balance is necessary to ensure the validity of the data. Third, a statistical error analysis must be performed to establish the range and bounds of the measurement values that have been determined experimentally. 


\subsection{Validation of Data}

Validation of the data will be performed according to the QAPP prepared for this experiment. The validation will be performed by an independent QA officer who is not directly involved with the sample handling and analysis.

\subsection{Data Reduction}

Data reduction in the tests will be used to determine the parameters identified in the standards identified in the previous section. Data analysis methods will be described in the reports to be prepared along with demonstration calculations. Specific calculations will be shown in the procedures to be developed and documented in Appendix A.

\section{DATA REPORTING}

A data package will be compiled as specified in the QAPP. This package will contain all of the pertinent information required to evaluate the characteristics of the waste form proposed for disposal at low-level waste facilities. The format and major elements of this data package are as follows:

- A project narrative that describes the experiment and contains the results from the experiment, including a compilation of the measurement values based upon the data analysis

- A case narrative that reports any anomalies that occur and any deviation from required procedures and the reasons for the deviations

- A hard copy of the data analysis workup

- Quality control summary sheets

- Data review and validation checklist from the PI

- Data verification checklist from the quality assurance officer

- Hard copies of the raw data

- $\quad$ Any pertinent notes from the laboratory notebook.

\section{REFERENCES}

1. "Technical Position on Waste Form (Revision 1)," NRC, January 1991.

2. "Licensing Requirements for land Disposal of Radioactive Waste," Code of Federal Regulations 10 CFR Part 61.

3. Workshop on Cement Stabilization of Low-Level Radioactive Waste, NUREG/CP-0103, NRC, 1989. 
4. American Society for Testing and Materials Standard Test Method for Compressive Strength of Cylindrical Concrete Specimens, ASTM C39, October 1984.

5. American Society for Testing and Materials Standard Test for Compression Strength of Bituminous Mixtures, ASTM D1074, 1980.

6. American Society for Testing and Materials Standard Test for the Thermal Cycling of Electroplated Plastics, ASTM B553, 1979.

7. American Society for Testing and Materials Standard Test for Determining Resistance of Synthetic Polymneric Materials to Fungi, ASTM G21, 1970.

8. American Society for Testing and Materials Standard Test for Determining Resistance of Plastics to Bacteria, ASTM G22, 1976.

9. "Measurement of the Leachability of Solidified Low-level Radioactive Wastes by a Short-term Test Procedure," ANSI/ANS Standard 16.1, American National Standards Institute/American Nuclear Society, 1988.

10. The Effect of Cure Conditions on the Stability of Cement Waste Forms After Immersion in Water," P. L. Piciulo and others, Brookhaven National Laboratory, WM-3171-4, 1987.

11. "Solid Radioactive Waste Processing System for Light Water Cooled Reactor Plants, Appendix 2," ANSI/ANS standard 55.1, American National Standards/American Nuclear Society, 1979.

12. "Licensing of Production and Utilization Facilities," Code of Federal Regulations 10 CFR Part 50. 